IZA DP No. 5752

The Employment of Mothers: Recent Developments and their Determinants in East and West Germany

Barbara Hanel

Regina T. Riphahn

May 2011 


\title{
The Employment of Mothers: Recent Developments and their Determinants in East and West Germany
}

\author{
Barbara Hanel \\ University of Melbourne \\ Regina T. Riphahn \\ University of Erlangen-Nuremberg \\ and IZA \\ Discussion Paper No. 5752 \\ May 2011 \\ IZA \\ P.O. Box 7240 \\ 53072 Bonn \\ Germany \\ Phone: +49-228-3894-0 \\ Fax: +49-228-3894-180 \\ E-mail: iza@iza.org
}

\begin{abstract}
Any opinions expressed here are those of the author(s) and not those of IZA. Research published in this series may include views on policy, but the institute itself takes no institutional policy positions.

The Institute for the Study of Labor (IZA) in Bonn is a local and virtual international research center and a place of communication between science, politics and business. IZA is an independent nonprofit organization supported by Deutsche Post Foundation. The center is associated with the University of Bonn and offers a stimulating research environment through its international network, workshops and conferences, data service, project support, research visits and doctoral program. IZA engages in (i) original and internationally competitive research in all fields of labor economics, (ii) development of policy concepts, and (iii) dissemination of research results and concepts to the interested public.
\end{abstract}

IZA Discussion Papers often represent preliminary work and are circulated to encourage discussion. Citation of such a paper should account for its provisional character. A revised version may be available directly from the author. 
IZA Discussion Paper No. 5752

May 2011

\section{ABSTRACT}

\section{The Employment of Mothers: Recent Developments and their Determinants in East and West Germany*}

We apply German Mikrozensus data for the period 1996 to 2004 to investigate the employment status of mothers. Specifically, we ask whether there are behavioral differences between mothers in East and West Germany, whether these differences disappear over time, and whether there are differences in the developments for high vs. low and medium skilled females. We find substantial differences in the employment behavior of East and West German mothers. German family policy sets incentives particularly for low income mothers not to return to the labor market after birth. East German mothers' employment outcomes matches that expected based on these policy incentives: over time East German mothers with low earnings potentials appear to adopt West German low employment patterns.

JEL Classification: J21, J13, J18

Keywords: employment, mothers, parental leave, East Germany, child care

Corresponding author:

Regina T. Riphahn

Economics Department

University of Erlangen-Nuremberg

Lange Gasse 20

D-90403 Nuremberg

Germany

E-mail: regina.riphahn@wiso.uni-erlangen.de

\footnotetext{
* This paper is forthcoming in Jahrbücher für Nationalökonomie und Statistik (Journal of Economics and Statistics). We thank the editor and three anonymous referees for constructive comments. Annette Bergemann, Esther Geisler, Conny Wunsch, and participants of the meeting of the Ausschuss für Bevölkerungsökonomik (Bamberg 2010), the Leopoldina-Economics and Empirical Sociology Section (Bonn 2010), and of the Mikrozensus users' conference (Mannheim 2009) provided helpful comments and suggestions.
} 


\section{Introduction}

Female labor force participation is a topic of political and scientific interest that is relevant in numerous ways: it affects the overall economic output of a society, it may influence child well-being, and it determines the development of female wages over the life cycle. In this study we investigate the development of employment choices of mothers in East and West Germany over time.

One of the core differences between the East and West German labor markets at unification was female labor force participation: "most of the $91 \%$ employed women in the East worked full-time, whereas only about three quarters of the $58 \%$ in West did so." (Adler and Brayfield, 1997, p. 248). West Germany had invited guest-workers to handle the labor shortage, while East Germany had pursued the full-time employment of females. The EastWest employment difference was particularly pronounced with respect to the employment of mothers. Kreyenfeld and Geisler (2006) document that as of 199164 percent of East German women with children were in full time employment compared to 21 percent in West Germany. Still in 1996, about 50 (80) percent of all East German mothers of two (ten) years olds were in the labor force compared to less than 30 (60) percent of all West German mothers of two years olds.

After unification the two regions of Germany differed economically, in their heritage, culture, and norms. At the same time they were governed by an identical institutional framework, which sets incentives for the employment behavior of mothers. We study whether the changes in East German mothers' employment match the incentives implicit in the newly imposed regulatory framework.

The literature on female labor force participation in East and West Germany points to a number of factors which affect the development of female employment outcomes over time: besides the incentives of family policies, market forces and a combination of culture, social norms and legacy affect behavior. After unification, overall employment in East Germany dropped from about 9 million in 1990 to 6 million in 1992 (Licht and Steiner 1994). The participation rates of females declined faster and unemployment rates rose more than 
those of males in the East (Rosenfeld et al. 2004, Hunt 2002). Some authors study norms and attitudes as potential determinants of employment differences of mothers in East and West Germany. Adler and Brayfield (1997) show that East German women assigned more importance to employment and that they were more likely to pursue a combination of motherhood and market career compared to West German mothers. Interestingly, Braun et al. (1994) argue that conditional on a higher valuation of employment, which was imposed by the socialist state, East German females were no less traditionalist in their attitudes than West Germans. Finally, Rosenfeld et al. (2004, p.110) point out that frequently behavioral adjustment may take some time because societies and individuals "arrange their lives in certain ways, just because that is what was done in the past."

Therefore, in studying behavior patterns of East German mothers over time we cannot assign causal effects to individual factors. Instead, we investigate at a descriptive level whether the observed adjustments in employment match institutionally set incentives and whether the adjustment of behavior over time occurs particularly among those mothers, who are affected most by these incentives. We will argue that these are mothers with low earnings potential. It is interesting to investigate and important to understand East-West differences in behaviors and their development over time.

Generally, the literature on female employment investigates the relevance of three factors: market and reservation wages, non-wage income (e.g. spousal earnings), and opportunity costs. The latter are affected by institutions such as parental leave or family related transfers. Many studies have looked at the impact of these institutions before, both, for single countries ${ }^{1}$ and in international comparison. ${ }^{2}$ The distinguishing feature of our contribution is its focus on the East-West German differences, their development over time and in specific subsamples.

1 See e.g. Barrow (1999), Klerman and Leibowitz (1999), Berger and Waldfogel (2004), Han et al. (2007, 2009) for the U.S., Gregg et al. (2007) and Burgess et al. (2008) for the U.K., Baker and Milligan (2008) for Canada.

2 Examples are Gustafsson et al. (1996), Ruhm (1998), Datta Gupta et al. (2008), Dearing et al. (2007), Geyer and Steiner (2007). 
The economic literature on East and West German mothers' employment consists of only a handful analyses. Bredtmann et al. (2009) compare East and West German mothers using retrospective data for the birth cohorts 1939-1945 who retired in 2004 and 2005. The authors study the two groups' employment and fertility decisions taken in the 1960s and 1970s. Kreyenfeld and Geisler (2006) use repeated cross-sectional data to compare East and West German mothers' employment behavior. They find that mothers in both regions reduced full time employment rates over time, with still much higher employment rates in the East and among the highly skilled in both regions. Bonin and Euwals (2005) focus on the difference between East and West German women using data from the 1990-1999 waves of the German Socio-Economic Panel. They jointly model participation, employment, and wages and find that East German women's participation behavior converged to western levels. However, this process was partly offset by the impact of low fertility and increased wages in East Germany after unification. ${ }^{3}$

We contribute to this literature in various ways: first, we use large samples drawn from the German Mikrozensus, which we pool over several years to compare the employment situation of East and West German mothers over time. Second, we follow the development of East-West German differences in female employment over time and, finally, we study whether the development of employment patterns differs across skill groups. ${ }^{4}$ The comparison of behavior across skill groups can provide suggestive evidence on the importance of policy incentives. We focus on whether mothers contribute substantially to the labor force and work at least 20 hours per week. Our empirical model controls for characteristics of the child, the mother, a partner, the household and the state and region of

$3 \quad$ In analyses for West German women only, Bender et al. (2003) study labor force participation patterns after a first birth for mothers born 1934-1971. Fitzenberger and Wunderlich (2004) compare employment behavior and its trends for various cohorts of West German and British females. Schönberg and Ludsteck (2007) study the employment response of West German mothers to extensions in parental leave coverage. They find significant wage drops even years after childbirth as a causal effect of parental leave taking. Tamm (2010) finds a substantial negative causal effect of an increase in child benefits on female labor market participation in the mid 1990s.

$4 \quad$ Fitzenberger and Wunderlich (2004) confirm differences in life-cycle employment patterns across skill groups. 
residence including local unemployment and child care utilization. ${ }^{5}$ We describe differences in the correlation patterns of East and West German maternal employment and study whether these differences disappeared over time.

Our main findings are that at each age of the youngest child the maternal propensity to work at least 20 hours per week is higher in East than in West Germany. Over time the difference has been decreasing. The decrease appears to be connected to behavioral changes among low and medium skilled East German mothers, who reduced their employment.

The paper is structured as follows: section 2 introduces institutional details of German family policies and derives our hypotheses; section 3 describes the data. Next, section 4 presents the estimation results in three steps: first we compare the correlates of the employment choices of East and West German mothers, then we evaluate changes over time, and finally we juxtapose the development for high vs. low and medium skilled mothers and provide some robustness tests. Section 5 concludes.

\section{Institutions, Incentives, and Hypotheses}

A variety of policy measures affected fertility and employment choices of the mothers in our data, i.e. since the early $1990 s .{ }^{6}$ In Germany, several financial benefits are available for parents of dependent children: monthly child benefit payments or child-related income tax exemptions, transfers from the social assistance program, from the unemployment, health, accident, and retirement insurances, means-tested benefits to support the education of children, or rent and home ownership subsidies for families. In addition, maternity leave and parental leave directly affect maternal labor market activity. Maternity leave regulates that mothers have to take paid leave for 6 weeks before and 8 weeks after childbirth. In that period they cannot be fired (e.g. Ondrich et al. 2003). Parental leave ("Erziehungsurlaub")

$5 \quad$ Several studies have pointed out that child care availability may be a key determinant of EastWest German differences in female labor market activity (see e.g. Büchel and Spieß 2002, or Wagner et al. 1995). Interestingly, Wrohlich (2008) points out that independent of child care availability and utilization patterns, excess demand for child care appears to be higher in East than in West Germany.

$6 \quad$ For a survey of institutional differences in East and West Germany prior to unification see Bredtmann et al. (2009). 
allows recent parents to take unpaid leave of their employment beyond maternity leave. After parental leave period parents can claim a job with their prior employer. The regulations permit parents to work up to 19 hours per week (since 200130 hours per week) while being on parental leave.

Generally, the incentives implicit in German family and tax policies differ depending on female earnings. First, direct transfers such as the means-tested childrearing benefits ("Erziehungsgeld") of 300 Euros per month indirectly impose a tax on labor earnings. This tax should affect the employment choices of women with low earnings potentials because for them childrearing benefits replace a relevant share of labor earnings. Childrearing benefits were paid if either the mother or the father worked no more than 19 hours per week after child birth, independent of whether they were employed before the birth. Since 1993, the monthly payout of 600 DM (later 300 Euros) extends to the first two years of a child's life. ${ }^{7}$

Second, the German income tax system entails a splitting rule which benefits couples with large differences in the two partners' earned incomes. The rule generates an artificially high tax burden on the lower of the two incomes which is typically earned by the wife. If both spouses earn similar amounts, the splitting rule generates no benefit and, accordingly, no tax induced disincentive to seek employment (for an evaluation of the incentive effects of the German income tax splitting rule see Dearing et al. 2007). ${ }^{8}$

Third, employment choices may be affected by heterogeneous child care cost and availability. Since 1996, German parents can claim child care for children aged three through six. However, the available number of full-time day care slots is still insufficient. Also, the

\footnotetext{
$7 \quad$ At the end of 2006 the "Erziehungsgeld" (childrearing) benefit was replaced by "Elterngeld" (parental leave benefit), available for births after January 1, 2007. The reform reduced the duration of the benefit payment from at most 24 to 12 months for any single partner (single parents are eligible for 14 months of benefits). If each of two partners takes at least 2 months then a total of 14 months of benefits is provided. At the same time the reform increased the benefit amount to up to two thirds of the pre-birth net income of the parent who interrupts employment. There is a minimum amount of 300 (also for those not previously in the labor force) and a maximum of 1,800 Euros per month. Since we look at data through 2004 here, this reform is not relevant for our analysis. For a first analysis see e.g. Bergemann and Riphahn (2010).

8 This effect of the income tax splitting system is complemented by the mandatory health insurance, where non-employed spouses and children are covered by the insurance premium of just one insured person, the working spouse. This similarly supports the male-breadwinner model. If the second spouse takes up employment, contributions to the health insurance are due without additional benefits.
} 
number of publicly available child care slots differs substantially between East and West Germany (see e.g. Grundig 2008 or Kreyenfeld and Geisler 2006): in 2008, full-day child care for children below age three was available for about 10 and 40 percent of all children in West and East Germany, respectively (Statistische Ämter 2009). Kreyenfeld and Geisler (2006) report increasing expenditures for child care over time. Even though child care expenditures may to some extent reduce taxable incomes, they do provide an additional tax on the income of those who seek employment instead of taking care of their children. Thus, employment in the presence of small children generates a net income only for those at the upper end of the income distribution. Together, these patterns suggest that the probability of labor force participation after a birth should decline with a woman's earnings potential.

In view of these policy incentives we expect an increasing polarization of employment among East German mothers over time. Specifically, our analyses focus on three hypotheses: (a) due to historic legacy and social norms regarding female employment (cf. Rosenfeld et al. 2004) female labor force participation continues to be higher in East than in West Germany. (b) Since the West German institutional framework was superimposed on the East German labor market after unification we expect a behavioral adjustment in East Germany. Based on the incentives implicit in this newly adopted institutional framework, we expect declining maternal employment rates. (c) Since the institutional framework (tax splitting, childrearing benefits, child care availability, and child care cost) discourages labor force participation particularly for women with low earnings potential, we expect a convergence to the lower employment rates of West German mothers particularly among low and medium skilled East German mothers.

\section{Data}

Our analysis is based on data taken from the Mikrozensus and covers the years 1996 to $2004 .^{9}$ The annually administered survey interviews about one percent of all German

\footnotetext{
$9 \quad$ Since we are interested in comparisons over time it is important to apply measures that were gathered consistently over time. This is ascertained for the considered time period in the Mikrozensus data. Before 1996 and after 2004 a number of issues (questionnaire, time of interview, sampling
} 
households. The scientific use files provide 70 percent of the available data. The Mikrozensus is a rotating panel in which every flat is visited up to four times. Since individuals cannot generally be identified across survey waves we pool cross-sectional data.

In our sample we consider all females aged 15 or above, who are the head of a family or partner of the head of a family, and with at least one child up to age 18 , independent of whether they are single mothers or live with a partner. ${ }^{10}$ To restrict the measurement error that may result from the lack of information on biological parenthood, we consider only women who are less than 45 years older than the youngest child living in the family. On average, we obtain about 57,000 observations for each survey year and a total of 514,273 observations for the pooled sample across all years, with 401,977 mothers in West and 112,296 in East Germany.

Our dependent variable indicates whether a mother is employed to a substantial extent. We consider every female employed who worked at least 20 hours in the week prior to the interview, including those who had a contract but did not work due to reasons such as illness, vacation, or short-time work. Individuals in irregular or minor employment and those supplying less than 20 hours of labor per week are not considered to be employed in our analysis. By using the 20 hours cutoff we consider all full time and most part time employed females and thus capture a solid attachment to the labor force. The 20 hours cutoff represents a common threshold value in German social law, used e.g. to separate regular and irregular employment and to limit e.g. employment while receiving parental leave benefits. Overall, 63.8 and 36.9 percent of East and West German mothers in our pooled sample are employed, respectively.

Based on these cross-sectional data we compare the correlation patterns of female substantial employment for East vs. West German mothers and determine the developments over time and across skill-subgroups. We consider females to be highly skilled, if they have a

frame) changed such that measures of employment outcomes may be affected if additional years are added to the analysis (for details see Körner and Puch 2009). The data was also applied by Tamm (2010).

10 The survey distinguishes the level of households and families, where a given household can potentially harbor several families. Our analyses are executed at the family level. 
master of crafts or technician degree, an East German engineering school degree, or a tertiary academic degree (university or polytechnic). ${ }^{11}$ All others are labeled low and medium skilled.

We apply a logit estimator and regress the individual employment outcome on (a) characteristics of the household, such as the age of the youngest child, the number and age composition of other children and the number of adults besides the partner living in the household, (b) characteristics of the mother, such as age, citizenship, education, and occupation, (c) the presence of a partner ${ }^{12}$ and his or her characteristics (citizenship, education, occupation ${ }^{13}$ ), and, finally, (d) a group of regional characteristics, i.e. the size of the community of residence, the state female unemployment rate, the state daycare utilization rate among children aged $0-2$, and the share of employees in the state that is employed in the public sector. The last three indicators are generated using the information available in the Mikrozensus data.

As a first piece of evidence, Figure 1 presents average rates of substantial employment for mothers in East and West Germany by the age of their youngest child in the sample pooled for the years 1996-2004. Clearly, employment rates are higher at all ages of the youngest child for mothers in East Germany. We consider a broad set of covariates to compare these employment patterns in East and West Germany. The covariates are described in Table 1 separately for the two regional subsamples. The asterisks in the last column of the table indicate that the characteristics of the regional subsamples differ significantly in the sample that is pooled over 9 years of data. Important differences relate to the average age of the youngest child, which as a result of the East German fertility decline after unification (Lechner 2001) is almost two years lower in West Germany. Due to different

\footnotetext{
$11 \quad$ Apprenticeships and school-based vocational degrees are grouped in the low skill group, as are all remaining categories. Individuals with an upper secondary school degree (Abitur) but no vocational training are considered in the low skill category. They make up 0.14 percent of the sample. ${ }_{12}$ We do not distinguish between married and non-married partners, both are considered jointly.

13 For those mothers who are not currently substantially employed we considered information on the last occupation they had held. When no information on current or past occupation is available for mothers with and without current employment, the observation is flagged using a missing value indicator. These observations make up 41 percent of sample.
} 
educational systems, the distribution of schooling degrees differs between East and West. We observe lower foreigner shares among mothers and their partners in East Germany as well as the expected East-West heterogeneity with respect to unemployment and childcare utilization.

\section{Results on Substantial Employment of Mothers}

\subsection{Comparing East and West}

Figure 1 and Table 1 already show that East German rates of substantial maternal employment exceed those of the West by on average more than 20 percentage points. ${ }^{14} \mathrm{We}$ apply regression analyses to determine first, whether this aggregate employment difference is a composition effect that relates back to East-West differences in observable characteristics and second, whether it reflects heterogeneous correlation patterns between characteristics and employment outcomes across the two regions.

In Table 2 specification 1 provides the results of a pooled logit regression of substantial maternal employment on household, maternal, and partner characteristics. The average difference between the two regional employment patterns is reflected in the highly significant coefficient of the indicator variable "East" at the bottom of the table. ${ }^{15}$ The marginal effect (presented in the Electronic Appendix) suggests that on average the rate of substantial employment of East German mothers exceeds that of their West German counterparts with identical characteristics by 12.8 percentage points. In specification 2 we add a set of regional characteristics to the model. Now the magnitude of the remaining eastwest difference increases and the average difference between observationally identical mothers in similar East and West German regions amounts to 15.6 percentage points (for marginal effects see the Electronic Appendix): if regional characteristics were more favorable in the East, maternal employment rates there might be even larger than observed.

14 We do not provide confidence intervals in our figures to avoid clutter. Confidence intervals are provided for the East German subsamples in the figures presented in the Electronic Appendix.

We provide heteroscedasticity robust standard errors as we cannot control for theoretically possible repeated observations of given mothers. 
In order to determine whether these employment differences relate back to heterogeneous regional correlation patterns between maternal characteristics and employment, we estimate a model that is fully interacted for the East German subsample. The results are presented in specification 3 of Table 2: they yield significantly different coefficient estimates for just about every covariate when the East German subsample is considered (see column labeled "Interaction: East"). In particular, we find a substantially steeper gradient in the probability of returning to substantial employment by the age of the youngest child in East Germany. Also, East German mothers appear to respond stronger to having additional young children living in the family than West German mothers. In East and West Germany higher educated females are more likely to work than those with only lower secondary school degrees. A significant difference appears for the group of (vocationally) highly skilled mothers: highly skilled East German women are substantially more likely to supply at least 20 hours of work per week. Different coefficient estimates are also obtained for maternal occupational groups in the two subsamples even though the descriptive statistics in Table 1 are not that different. In both regions single mothers work less than those with a partner. The correlation between partner characteristics in terms of citizenship, education, and occupation differ again substantially between East and West. Regional indicators such as community size, unemployment rate, childcare utilization, and share of public sector employment mostly yield different coefficients in East and West Germany: rates of substantial employment in East Germany are highest in the smallest communities, while in the West they are highest in the largest communities. ${ }^{16}$ High regional female unemployment is negatively correlated with the probability that mothers are employed at least 20 hours per week; this correlation is much stronger in East than in West Germany, which might indicate that the buffer of females out of the labor force is smaller in East than in West Germany. The bottom of Table 2 provides time trend estimates (row labeled "Year"), which are negative for all groups but significantly larger for the East German sample. This matches our hypothesis:

16 Tests for the joint statistical significance of the groups of indicators and of interaction terms yield that all groups of interaction terms are jointly significantly different from zero. 
the propensity to supply at least 20 hours of work per week declined among mothers in East and West Germany over time, but it declined more rapidly in East Germany.

\subsection{Comparing Changes over Time in East and West}

Since we suspect that labor market behavior assimilated over time between the East and the West German subsamples, Figure 2 presents the propensity of substantial employment by the age of the youngest child separately for the first and the last year of our data, i.e. 1996 and 2004: employment propensities in West Germany hardly changed over time, while the average employment rate of East German mothers declined, particularly for mothers of children in school, i.e. age 6 and above. Appendix Table A.1 presents the change in the two regional subsamples' characteristics over time. The last column in Table A.1 indicates those characteristics for which developments over time differ significantly between the regions: the regions may either become more similar or more different, which depending on the direction of the marginal effects - might render regional employment outcomes more or less similar.

To determine whether the behavioral differences between the East and West German mothers disappeared over time, we reestimated the logit specification described above, this time considering time interactions in addition to the regionally interacted vector of covariates, which we inspected in specification 3 of Table 2. Using a logit link function (f), the model now estimates coefficient vectors $\alpha, \beta, \gamma$, and $\delta$ for the original covariates $(X)$, their interactions for East Germans, interactions with a linear time trend (Year), and a double interaction of $X$ with the East German and the time trend variables for each individual i:

$$
\operatorname{Pr}\left(\text { employment }_{i}=1\right)=f\left[\alpha^{\prime} X_{i}+\beta^{\prime}\left(X_{i} \cdot \text { East }_{i}\right)+\gamma^{\prime}\left(X_{i} \cdot \text { Year }_{i}\right)+\delta^{\prime}\left(X_{i} \cdot \text { Year }_{i} \cdot \text { East }_{i}\right)\right]
$$

The estimation results are presented in Table 3 . Again we find a much steeper gradient in the propensity of substantial employment among East than West German mothers with respect to the age of their youngest child (see column 2 labeled "Interaction: 
East"). Column 3 (labeled "Interaction: Time") presents the estimated coefficients for the time interactions ( $(\mathrm{y})$ : while most coefficient estimates are individually statistically insignificant, most groups of indicators are jointly significant (test results are provided in the Electronic Appendix). They indicate, e.g., shifts in the correlation patterns between occupation and employment over time and increasing employment gradients by the age of the youngest child for West German mothers.

The final column (labeled "Int.: East Time") presents the coefficient estimates of the East German interaction terms from Column 2 interacted again with the year of observation (ঠ). This yields whether developments in correlation patterns over time differ for the East German mothers and whether the difference between East and West German mothers changed over time. As an example, the first row describes the correlation of having a one year old child with maternal employment: for West German mothers the employment probability is (insignificantly) higher if the child is one year old than if it is below age one (a positive entry of 0.032 ), this difference is (insignificantly) more pronounced for east German mothers (see the entry of 0.161 in the next column). The third column shows that the correlation increased insignificantly over time for West German mothers (see the coefficient of 0.014 ). The entry in the final column (coefficient of 0.057 ) yields a significantly steeper development over time in the correlation of substantial employment with having a one year old for East than for West German mothers.

The coefficients of the double interaction terms of the age of the youngest child with time and the east indicator are jointly highly statistically significant at the 0.1 percent level. The coefficients reflect the drop over time in the East German employment gradient, as seen in Figure 2. The effects are individually as well as jointly statistically significant and obviously not explained by other shifts in the sample composition or correlation patterns over time. We interpret these results as evidence of behavioral changes among East German mothers, who on average reduce their propensity to work at least 20 hours per week over time. Hardly any of the other coefficient estimates in the last column are significantly different from zero. We conclude from this part of the analysis that most of the differences in the employment 
correlations between East and West German mothers remained stable over time. Nevertheless, confirming Figure 2, the employment propensity of East German mothers of youth aged 5 and above fell significantly over time. This may be driven by responses to policy incentives.

At the same time the propensity of mothers of one year old children to work at least 20 hours increased significantly between 1996 and 2004. We can only speculate that this is related to a shift in the provision of childrearing benefits ("Erziehungsgeld"): since 2001 these benefits could be received in a blocked version for a shorter period of time, i.e. instead of 307 Euro for 24 months 460 Euros were paid for up to 12 months. The blocked version was used particularly often in East Germany and it might explain the secular increase in employment at age one of the child (see Fendrich et al. 2005).

In the next section we compare the behavioral adjustments of mothers who should be differently affected by policy changes. This will provide further suggestive evidence on the relevance of policy shifts.

\subsection{Comparing Changes over Time in East and West by Skill Group}

Our last hypothesis suggests that developments in the substantial employment propensity of East German mothers differ by skill level and earnings potential. We expect declining employment rates particularly among mothers with lower expected earnings, because the West German institutional framework (tax incentives, family policies, declining child care availability, etc.) provides disincentives for the employment of East German mothers with lower skill levels.

Figures $\mathbf{3 a}$ and $\mathbf{3} \mathbf{b}$ depict the aggregate shifts in the rates of substantial employment over time and again by the age of the youngest child separately for high vs. low and medium skilled mothers. In both regions of the country, employment rates among the high skilled exceed those of the low and medium skilled by up to 20 percentage points in 1996 (descriptive statistics for high vs. low and medium skilled mothers in East and West over time are presented in Appendix Table A.2). The behavior of high skilled mothers is about constant 
over time in West Germany and dropped only slightly among East German mothers (see Figure 3b). In contrast, substantial employment rates among low and medium skilled East German females declined strongly by 2004 , while those of low and medium skilled mothers in West Germany remained about constant (see Figure 3a). This matches our expectation of heterogeneity in the East German adjustment process to West German employment patterns.

Again, we applied multivariate regression analysis to test whether there are differences in behavioral adjustments, this time comparing time trends in East-West substantial employment differences by skill group. We repeated the estimations in Table 3 separately, for two skill groups. The results are presented in Tables 4.1 (high skill mothers) and Table 4.2 (low and medium skill mothers). As before, we obtain highly significant coefficient estimates of the East German interaction terms in the second column for both subsamples. The time interactions for the West German subsample in column 3 hardly yield significant coefficient estimates. To understand the developments in East vs. West Germany over time we focus on the results in the last column. For the high skill sample in Table 4.1 we hardly obtain statistically significant coefficient estimates. The interaction terms for the age of the youngest child are jointly statistically significant at the 5 percent level (see test statistics at the bottom of the table). Altogether, this indicates that the time effects do not differ strongly between East and West German high skill mothers and that the difference between East and West dropped only slightly over time. This confirms the evidence from Figure $\mathbf{3 b}$, where no major changes occurred over time in the substantial employment of highly skilled mothers.

The situation is different for mothers with low and medium skills, see Table 4.2. Here, the last column contains individually highly statistically significant coefficient estimates for the indicators of the age of the youngest child. The coefficient vector is jointly highly significant at the 0.1 percent level. The negative coefficients indicate that the difference in substantial employment declined over time between East and West German low and medium skill mothers of children aged 5 and above. Since the time interactions for West Germany (see column 3, labeled "Interaction: Time") are insignificant it appears that East German mothers 
reduced their rates of substantial employment over time by more than their West German counterparts. This adjustment is not connected to any specific set of individual characteristics but appears to generally affect mothers of all school aged children. This drop in substantial employment among low and medium skilled mothers matches our expectations based on the institutionally set incentives.

\subsection{Robustness Tests}

We performed robustness tests, both, changing the composition of the sample and adjusting the definition of the dependent variable. Since the differences in behavior might in part be due to differences between single mothers and those living with a partner, we repeated our graphical analysis now looking only at mothers living with a partner. Figure 4 depicts the development of substantial employment for these mothers by skill level. The results are highly robust: again it is the low and medium skilled East German subsample that changed behavior the most and according to our hypothesized patterns.

It is well known that the majority of the German immigrant population resides in West Germany (see Table 1 for descriptive statistics). It is thus possible that immigrant mothers affect the observed differences. To test whether our results are robust we redid our analyses after dropping observations of individuals without German citizenship. Figure $\mathbf{5}$ presents the evidence for the modified sample. It corroborates our conclusions.

So far, our dependent variable considered substantial employment as the relevant outcome. As unemployment rates are much higher in East than in West Germany and because the unemployment risk may be correlated with the maternal skill level, it is of interest to investigate the labor force participation rate without conditioning on employment of at least 20 hours per week. In Figure 6 we show how maternal labor force participation (combining employment and job search ${ }^{17}$ ) develops by age of the youngest child and maternal skill group over time. The shape of the labor force participation profiles in Figure 6 resembles that presented in Figure 3 above. Again, low and medium skilled mothers reduce

$17 \quad$ Mothers are coded as searching if they indicated that they both wish to be employed and are available for work within two weeks. 
their involvement over time particularly if the youngest child was aged 6 and above. While labor force participation rates in East Germany are quite high when searching mothers are considered as well, the general pattern of no clear drop among the high skilled and a clear drop among the low and medium skilled of up to 16 percentage points remains. ${ }^{18}$ This confirms that the decline in substantial employment is not driven by general unemployment in East Germany. Rather, policy-based incentives are likely to be among its determinants. ${ }^{19}$

\section{Conclusions}

We use evidence from repeated annual cross-sectional samples taken from the German Mikrozensus to describe the patterns of substantial employment among mothers in recent years. We focus on a comparison of behavior patterns in East and West Germany and study developments over time. We consider regular part-time and full-time jobs with at least 20 hours of employment per week, rather than irregular or minor employment.

Given that the East German mothers in our data grew up in an environment where female labor force participation was the rule and even demanded, we expect to see continued behavioral differences between East and West German mothers. ${ }^{20}$ We test the overall persistence of behavioral differences over time and cannot reject that the employment propensity is much higher in East than in West Germany even in more recent times.

Based on the regulations of German tax, social insurance, and family policies there is a substantially reduced incentive for mothers to seek employment compared to the institutional framework of the German Democratic Republic. Therefore we expect that over time the difference in the propensity of substantial employment between East and West German mothers declines. We indeed find such patterns.

18 In addition, we re-estimated the specifications in Tables 2-4 using labor force participation as a dependent variable (results are available in the Electronic Appendix). The results corroborate our findings.

${ }_{19}$ If (a) discouragement causes respondents to not indicate that they are searching for a job and if (b) this problem occurs systematically more often for women with young school-aged children, then discouragement might provide an additional rationale for the drop in maternal labor force participation over time.

${ }_{20}$ However, in view of the changed cultural, economic and political climate of the society Adler and Brayfield (1997, p. 264) suggested: "Proponents of assimilation and rational choice arguments would expect East German women's work attitudes to become less favorable, and hence more similar, to those of West German women in the near future." 
The negative employment incentives implicit in the German institutional framework particularly affect females with low earnings potential. Therefore we hypothesize that the decline in the propensity of substantial employment among East German mothers might be concentrated in that group. The results of our analyses confirm those expectations: the general decline of East German employment rates over time was driven by women with lower occupational skills and earnings potentials.

One might argue that the observed developments are due to high unemployment rates in East Germany. However, first, we controlled for overall differences between East and West Germany in our multivariate models, which should capture any aggregate differences such as unemployment. In addition, we tested the robustness of our results by considering also mothers searching for jobs in our dependent variable. The results showed that even the combined group of employed and searching mothers shrunk over time in East Germany.

In a study of the development of the gender wage gap in East Germany after reunification Hunt (2002) shows that the employment of low skilled East German females dropped in the years after unification and that the birth of a child has a very large impact on female employment attachment. Our results show, that one might add "incentives of family policy" to her list of potential explanations of these developments (p.167): "Societal pressure to leave jobs for men, a taste for more leisure or household production, and geographical inflexibility could explain the remaining gender gap in the employment hazard. However, the results indicate that a decline in child-care availability is unlikely to have been important ..."

In sum, the behavioral differences between East and West German mothers declined since the early years after German unification, but persist until recently. We find that only low and medium skilled East German mothers changed their behavior over time. Since this is the group, which is predominantly affected by policy incentives, it is plausible that institutional incentives are one of the possible determinants of this development. ${ }^{21}$ If increased female

$21 \quad$ However, we cannot exclude the possibility that other mechanisms are at work as well, such as skill biased technological or shifts in industry composition that differently affect high and non-high skilled females in East and West Germany. Any such mechanism must exert its effect even conditional on a linear time trend and it must explain the effect on the employment propensity of mothers of young children. 
labor force participation is a political objective, e.g. to balance reduced labor supply connected to population aging, then reforms of the institutionally set incentives should be considered by policy makers. 


\section{Bibliography}

Adler, Marina A. and April Brayfield, 1997, Women's Work Values in Unified Germany, Work and Occupations 24, 245-266.

Baker, Michael and Kevin Milligan, 2008, How Does Job-Protected Maternity Leave Affect Mothers' Employment?, Journal of Labor Economics 26(4), 655-691.

Barrow, Lisa, 1999, An Analysis of Women's Return-to-Work Decisions Following First Birth, Economic Inquiry 37(3), 432-451.

Bender, Stefan, Annette Kohlmann, and Stefan Lang, 2003, Women, Work, and Motherhood, MPIDR Working Paper No. 2003-006, Rostock.

Bergemann, Annette and Regina T. Riphahn, 2010, Female labor supply and parental leave benefits. The causal effect of paying higher transfers for a shorter period of time, forthcoming: Applied Economics Letters.

Berger, Lawrence and Jane Waldfogel, 2004, Maternity Leave and the Employment of New Mothers in the United States, Journal of Population Economics 17(2), 331-349.

BMFSFJ (Bundesministerium für Familie, Senioren, Frauen und Jugend), 2009, Familienreport 2009. Leistungen. Wirkungen, Trends, Berlin.

Bonin, Holger and Rob Euwals, 2005, Why are labor force participation rates of East German women so high?, Applied Economics Quarterly 51(4), 359-386.

Braun, Michael, Jacqueline Scott, and Duane F. Alwin, 1994, Economic necessity or selfactualization? Attitudes toward women's labour-force participation in East and West Germany, European Sociological Review 10(1), 29-47.

Bredtmann, Julia, Jochen Kluve, and Sandra Schaffer, 2009, Women's Fertility and Employment Decision under two Political Systems: Comparing East and West Germany before Unification, Ruhr Economic Papers No. 149, Bochum.

Büchel, Felix and C. Katharina Spieß, 2002, Kindertageseinrichtungen und Müttererwerbstätigkeit - Neue Ergebnisse zu einem bekannten Zusammenhang, Vierteljahreshefte zur Wirtschaftsforschung 71, 95-113.

Burgess, Simon, Paul Gregg, Carol Propper, and Elizabeth Washbrook, 2008, Maternity Rights and Mothers' Return to Work, Labour Economics 15(2), 168-201.

Datta Gupta, Nabanita, Nina Smith, and Mette Verner, 2008, The Impact of Nordic Countries' Family Friendly Policies on Employment, Wages, and Children, Review of Economics of the Household 6, 65-89.

Dearing, Helene, Helmut Hofer, Christine Lietz, Rudolf Winter-Ebmer, and Katharina Wrohlich, 2007, Why Are Mothers Working Longer Hours in Austria than in Germany? A Comparative Microsimulation Analysis, Fiscal Studies 28(4), 463-495.

Fendrich, Sarah, Jörg Fischer, and Matthias Schilling, 2005, Erziehungsgeld und Elternzeit. Bericht des Jahres 2003, Dortmunder Arbeitsstelle Kinder- und Jugendhilfestatistik.

Fitzenberger, Bernd and Gaby Wunderlich, 2004, The Changing Life Cycle Pattern in Female Employment: A Comparison of Germany and the U.K., Scottish Journal of Political Economy 51(3), 302-328.

Geyer, Johannes and Viktor Steiner, 2007, Short-Run and Long-Term Effects of Childbirth on Mothers' Employment and Working Hours Across Institutional Regimes: An Empirical Analysis Based on the European Community Household Panel, IZA Discussion Paper No. 2693, Bonn.

Gregg, Paul, Maria Gutierrez-Domenech, and Jane Waldfogel, 2007, The Employment of Married Mothers in Great Britain, 1974-2000, Economica 74(296), 842-864. 
Grundig, Beate, 2008, Why is the share of women willing to work in East Germany larger than in West Germany? A logit model of extensive labour supply decision, ifo Working Paper No. 56, Munich.

Gustafsson, Siv S., Cecile M.M.P. Wetzels, Jan Dirk Vlasblom, and Shirley Dex, 1996, Women's Labor Force Transisions in Connection with Childbirth: A Panel Data Comparison between Germany, Sweden and Great Britain, Journal of Population Economics 9(3), 223-246.

Han, Wen-Jui, Christopher Ruhm, and Jane Waldfogel, 2007, Parental Leave Policies and Parents' Employment and Leave-Taking, NBER Working Paper 13697, Cambridge Mass.

Han, Wen-Jui, Christopher Ruhm, Jane Waldfogel, and Elizabeth Washbrook, 2009, Public Policies and Women's Employment after Childbearing, NBER Working Paper 14660, Cambridge Mass.

Hunt, Jennifer, 2002, The Transition in East Germany: When Is a Ten-Point Fall in the Gender Wage Gap Bad News?, Journal of Labor Economics 20(1), 148-169.

Klerman, Jacob Alex and Arleen Leibowitz, 1999, Job Continuity among New Mothers, Demography 36(2), 145-155.

Körner, Thomas and Katharina Puch, 2009, Der Mikrozensus im Kontext anderer Arbeitsmarktstatistiken, Wirtschaft und Statistik 6/2009, 528-552.

Kreyenfeld, Michaela and Esther Geisler, 2006, Müttererwerbstätigkeit in Ost- und Westdeutschland, Zeitschrift für Familienforschung 18(3), 333-360.

Lechner, Michael, 2001, The Empirical Analysis of East German Fertility after Unification: An Update, European Journal of Population 17(1), 61-74.

Ondrich, Jan, C. Katharina Spiess, Ying Yang, and Gerd G. Wagner, 2003, The Liberalization of Maternity Leave Policy and the Return to Work after Childbirth in Germany, Review of Economics of the Household 1, 77-110.

Orlowski, Robert and Regina T. Riphahn, 2009, The East German Wage Structure after Transition, Economics of Transition 17(4), 629-659.

Rosenfeld, Rachel A., Heike Trappe, and Janet C. Gornick, 2004, Gender and Work in Germany: Before and After Reunification, Annual Review of Sociology 30, 103-124.

Ruhm, Christopher J., 1998, The Economic Consequences of Parental Leave Mandates: Lessons from Europe, Quarterly Journal of Economics 113(1), 285-317.

Schönberg, Uta and Johannes Ludsteck, 2007, Maternity Leave Legislation, Female Labor Supply, and the Family Wage Gap, IZA Discussion Paper No. 2699, Bonn.

Statistische Ämter des Bundes und der Länder, 2009, Kindertagesbetreuung regional 2008. Ein Vergleich aller 429 Kreise in Deutschland, Wiesbaden.

Tamm, Marcus, 2010, Child Benefit Reform and Labor Market Participation, Jahrbücher für Nationalökonomie und Statistik (Journal of Economics and Statistics) 230(3), 313327.

Wagner, Gert G., Karsten Hank, and Katja Tillmann, 1995, Außerhäusige Kinderbetreuung in Ostdeutschland - 1990 und 1994 im Vergleich zu Westdeutschland, Diskussionspapiere aus der Fakultät für Sozialwissenschaft der Ruhr-Universität Bochum, Nr. 95-18.

Wrohlich, Katharina, 2008, The excess demand for subsidized child care in Germany, Applied Economics 40(10-12), 1217-1228. 
Figure 1 Average Substantial Employment Rates for Mothers in East and West Germany by the Age of the Youngest Child (Data Pooled 1996-2004)

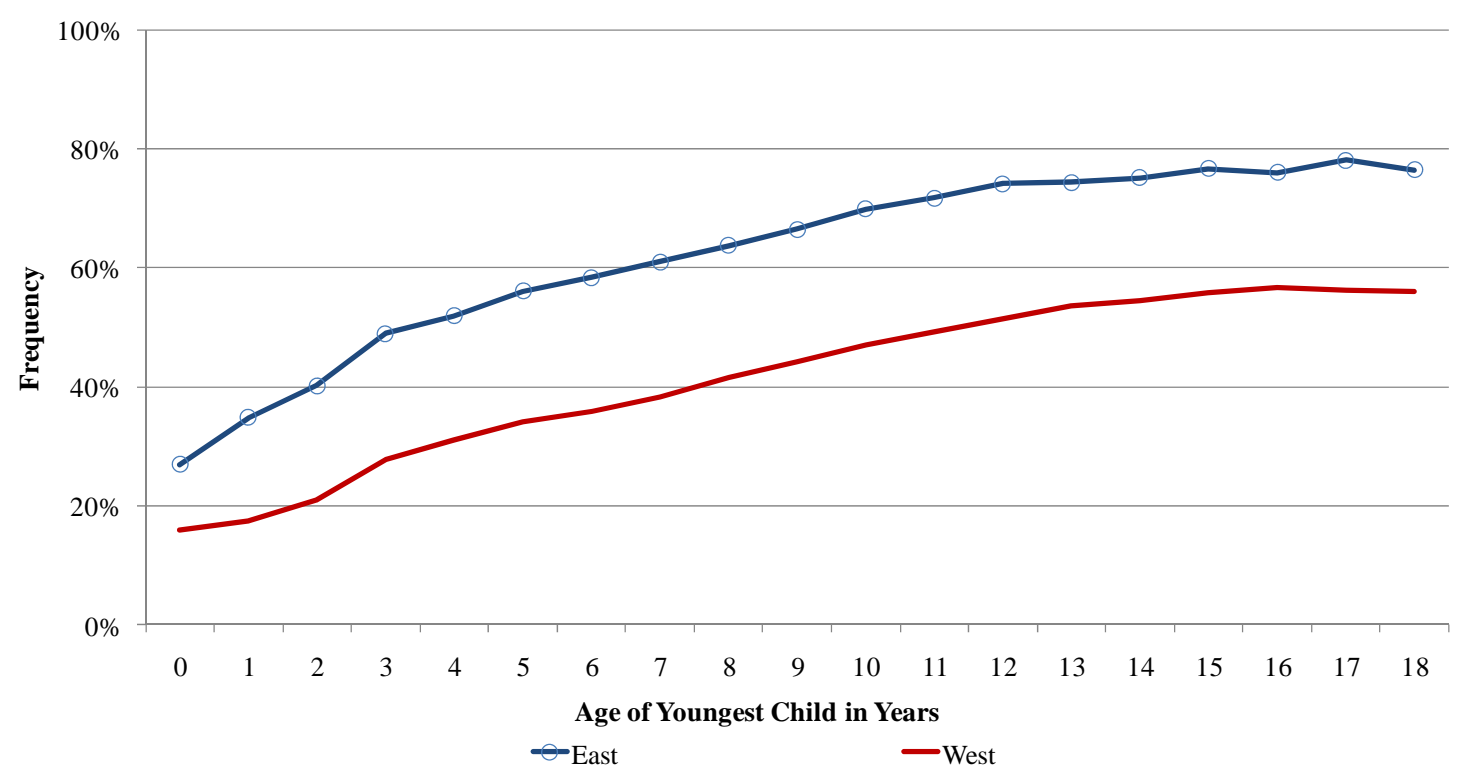

Source: Mikrozensus 1996-2004.

Figure 2 Average Substantial Employment Rates for Mothers in East and West Germany by the Age of the Youngest Child and Year (1996 versus 2004)

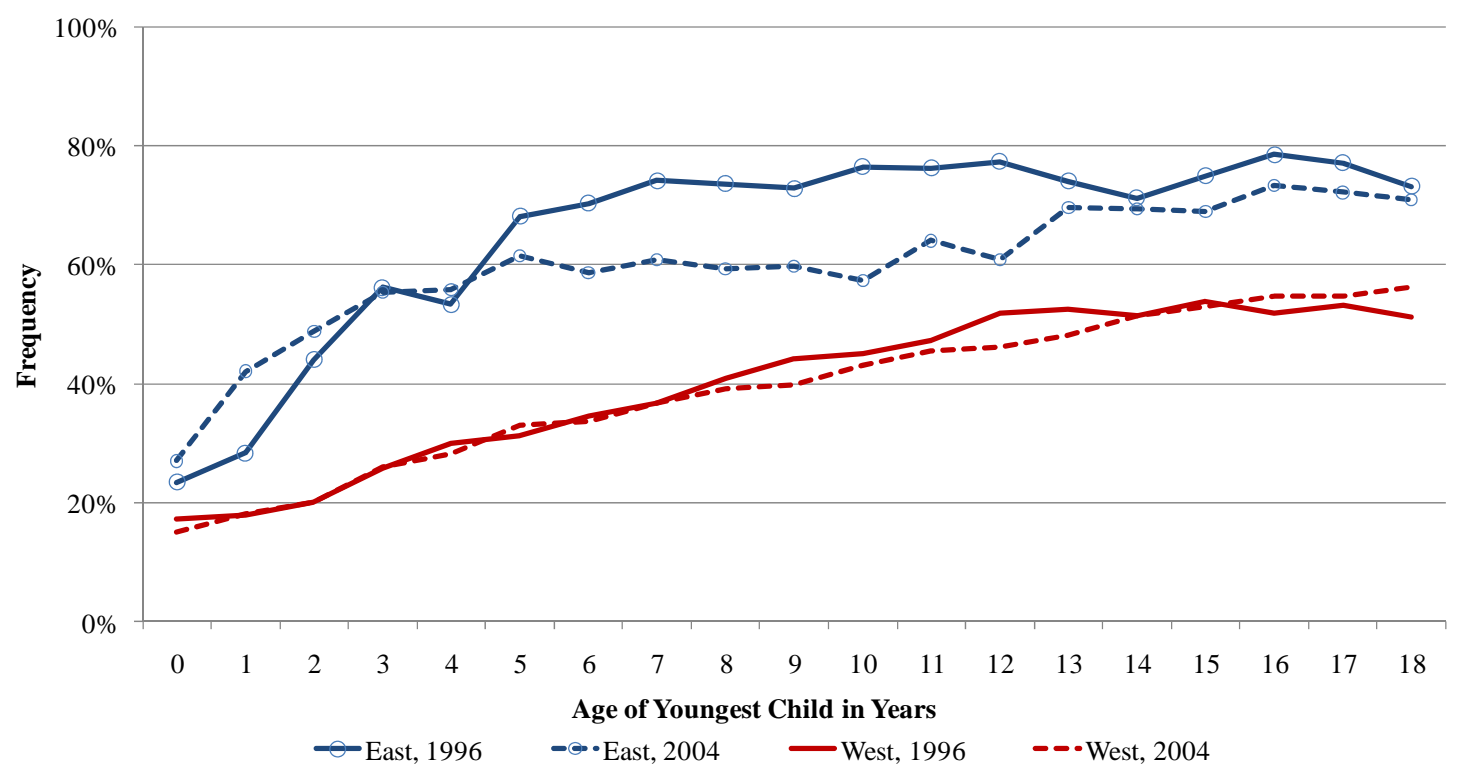

Source: Mikrozensus 1996-2004. 
Figure 3 Average Substantial Employment Rates for Mothers in East and West Germany by Skill, the Age of the Youngest Child and Year (1996 versus 2004)

(a) Low and Medium Skilled Mothers

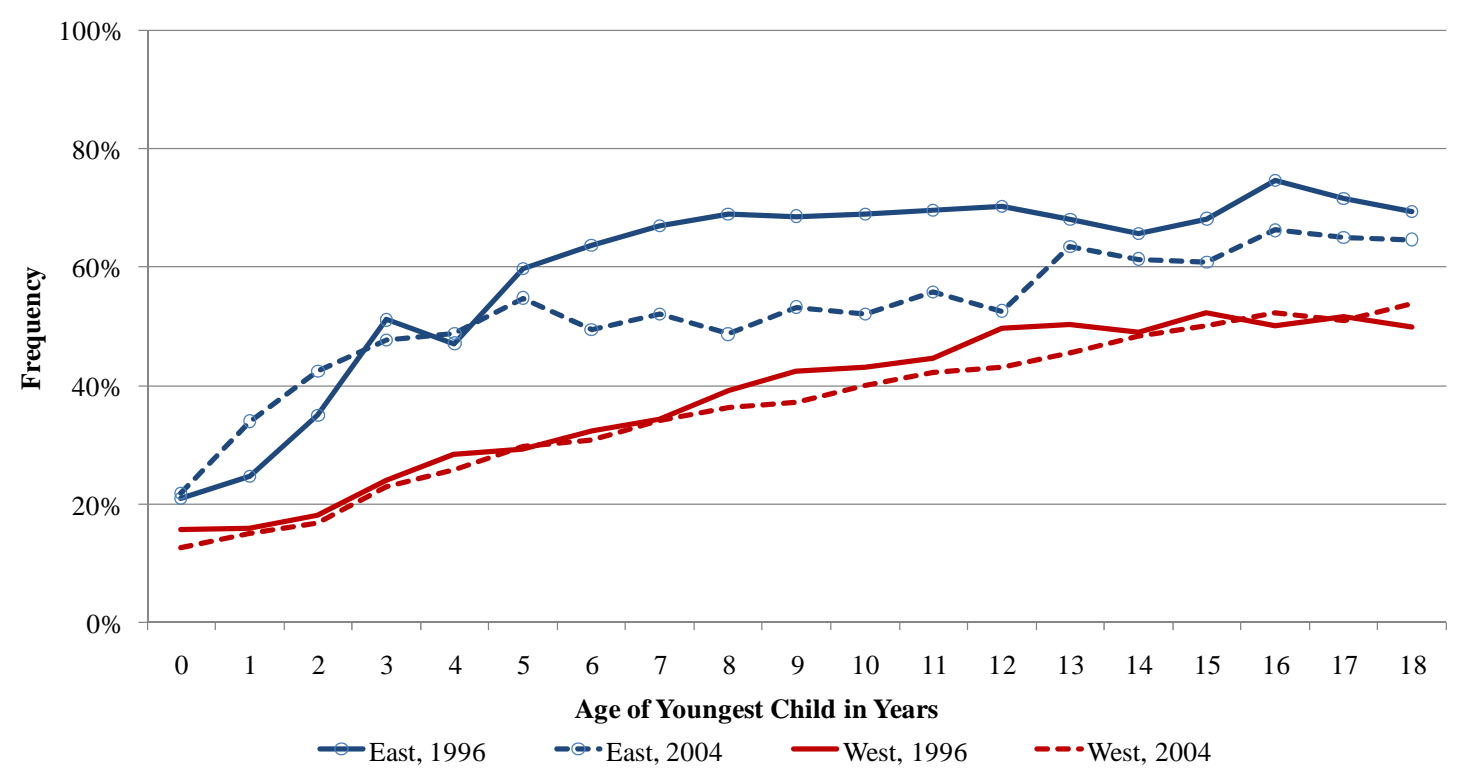

(b) High Skilled Mothers

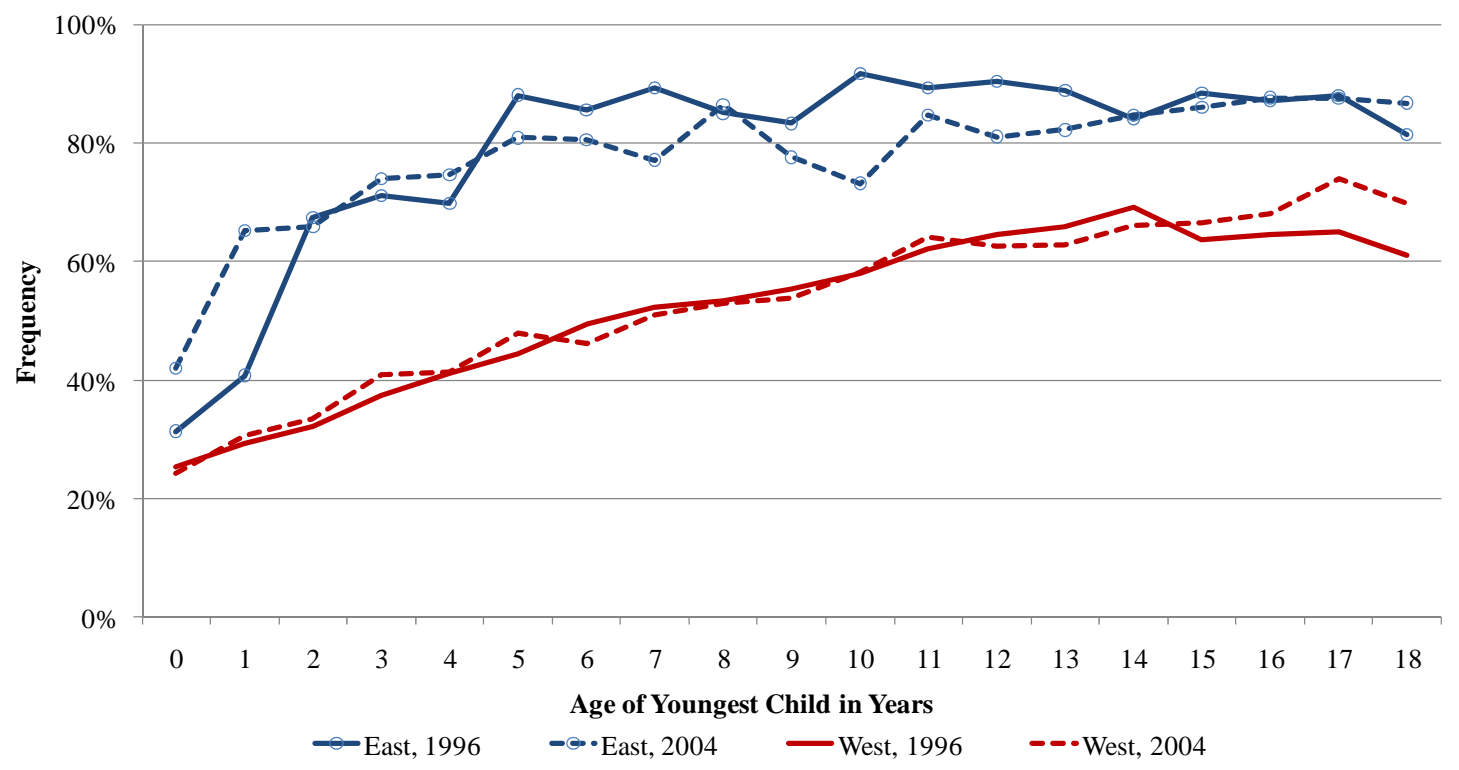

Source: Mikrozensus 1996-2004. 
Figure $4 \quad$ Average Substantial Employment Rates for Mothers with a Partner in East and West Germany by Skill, the Age of the Youngest Child and Year (1996 versus 2004)

(a) Low and Medium Skilled Mothers

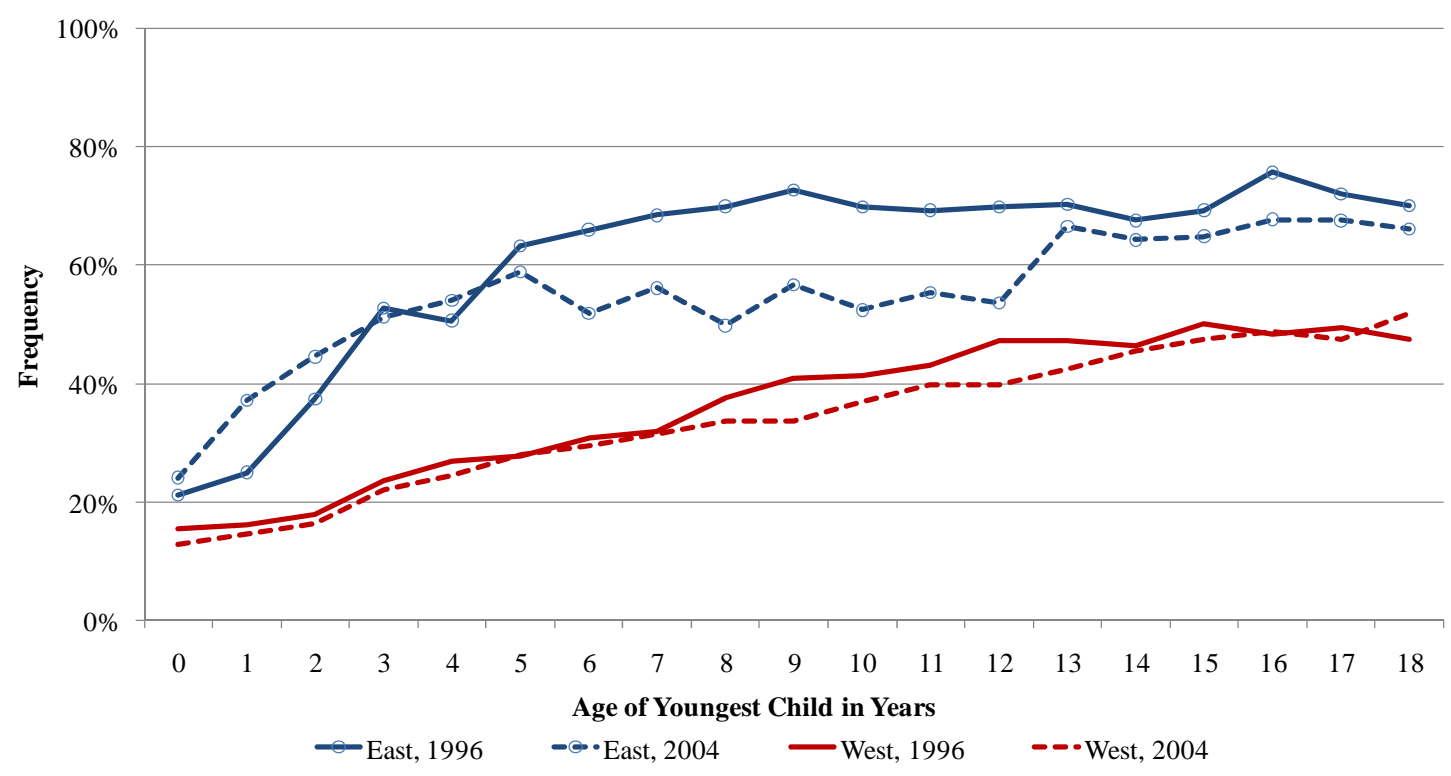

(b) High Skilled Mothers

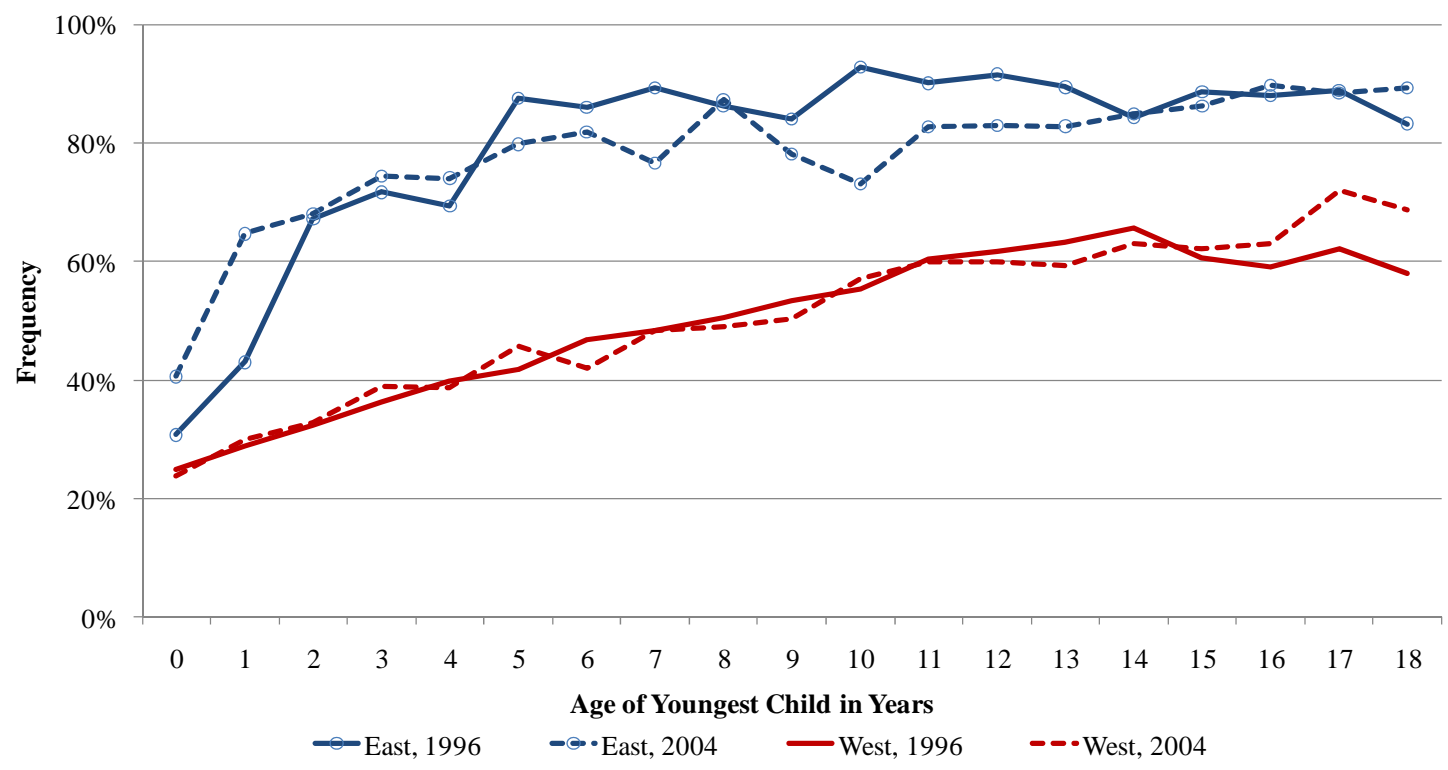

Source: Mikrozensus 1996-2004. 
Figure $5 \quad$ Average Substantial Employment Rates for Mothers with German Citizenship in East and West Germany by Skill, the Age of the Youngest Child and Year (1996 versus 2004)

(a) Low and Medium Skilled Mothers

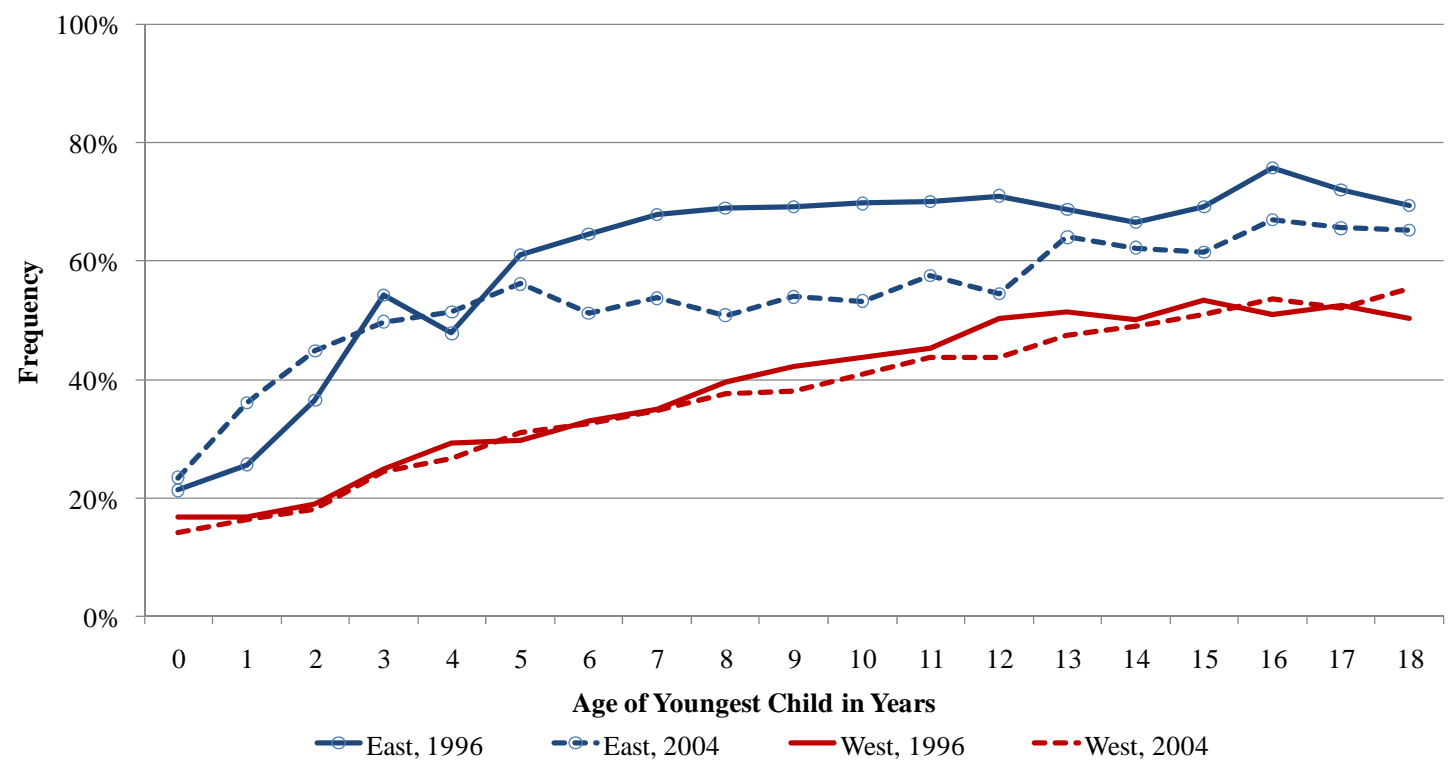

(b) High Skilled Mothers

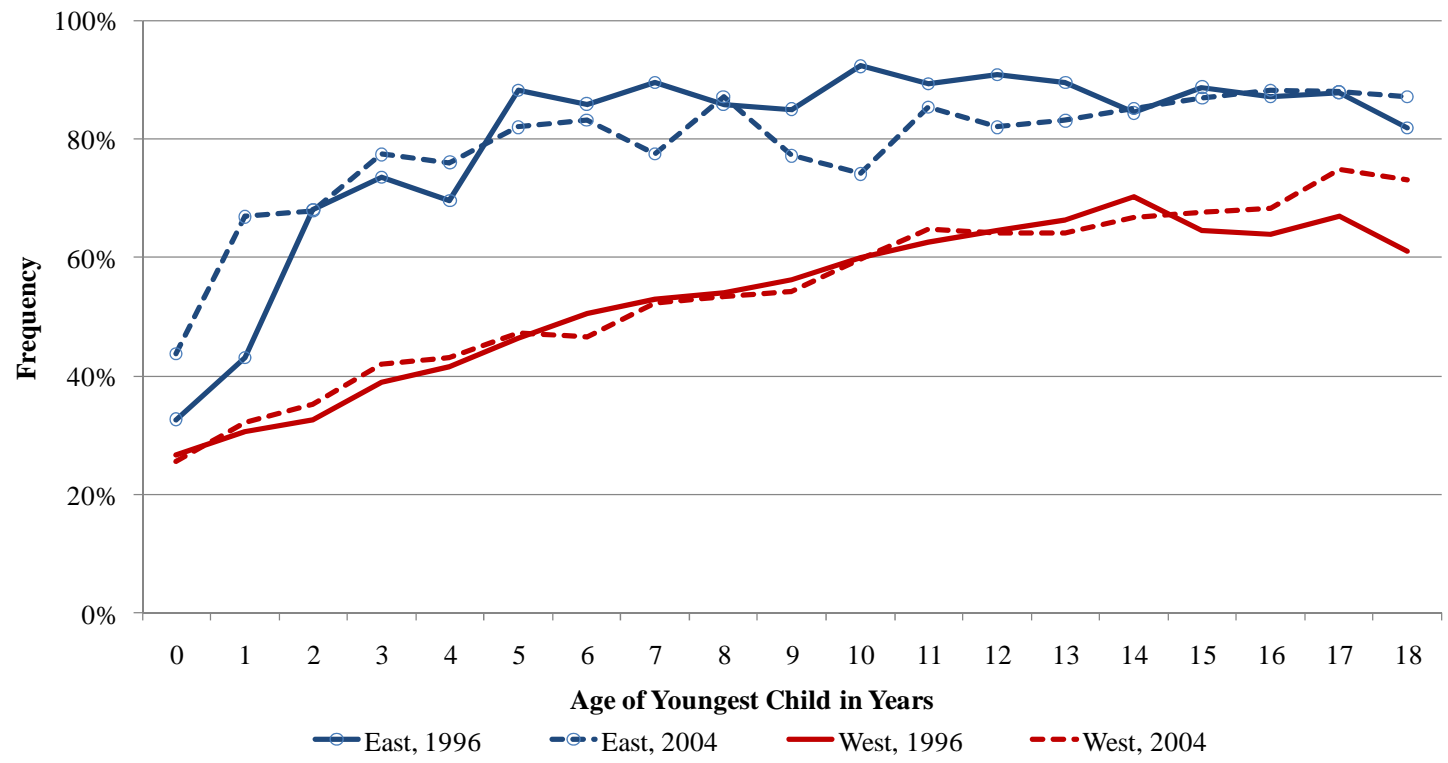

Source: Mikrozensus 1996-2004. 
Figure 6 Average Labor Force Participation (i.e. Substantial Employment and Search) Rates for Mothers in East and West Germany by Skill, the Age of the Youngest Child and Year (1996 versus 2004)

(a) Low and Medium Skilled Mothers

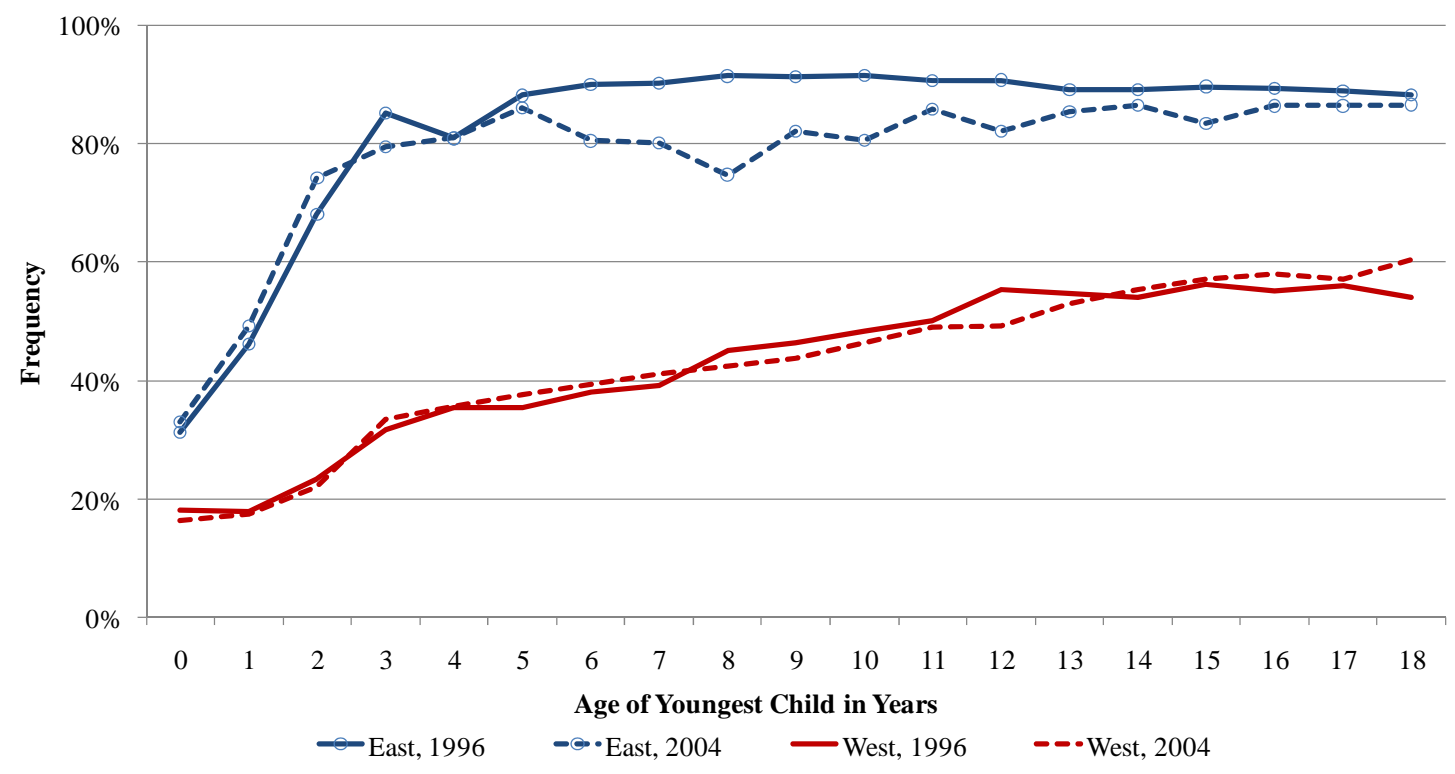

(b) High Skilled Mothers

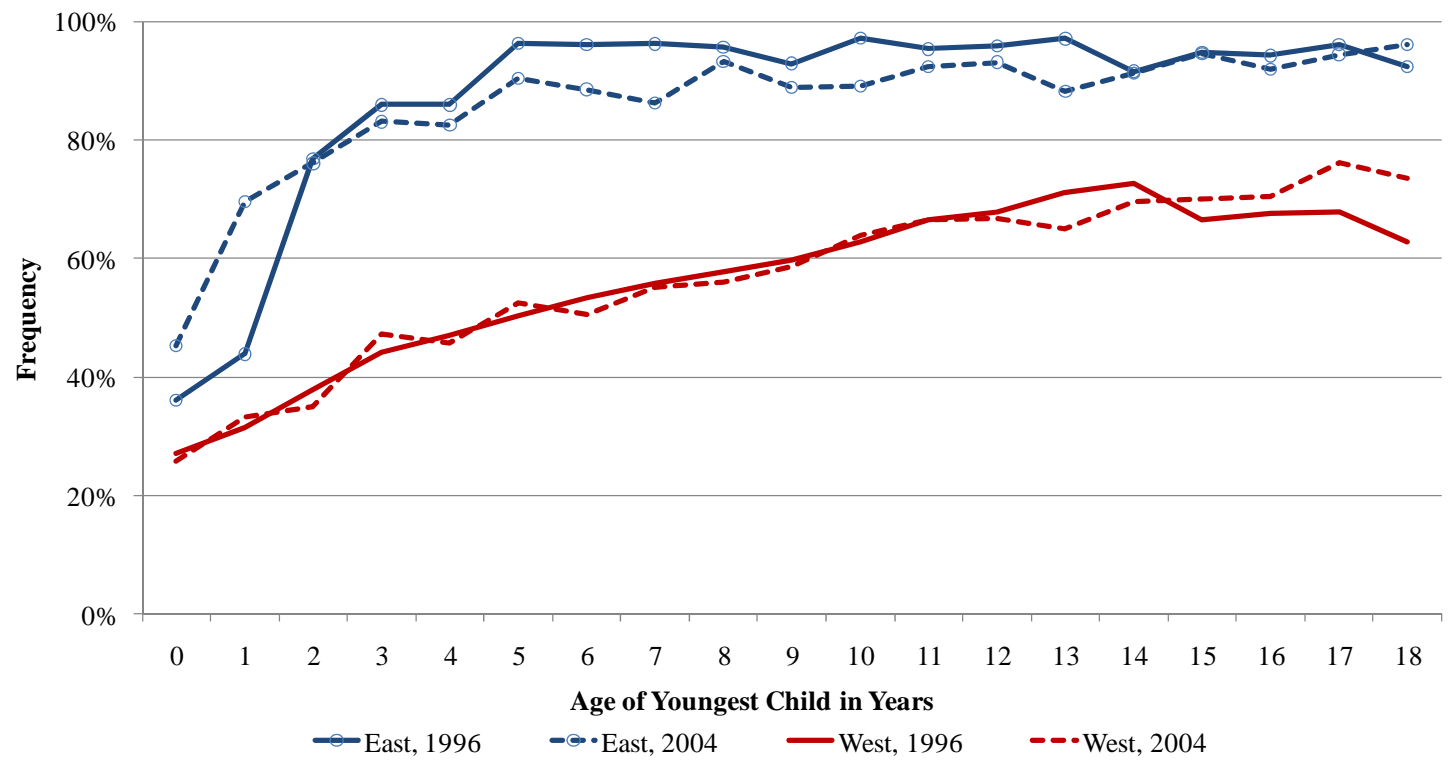

Source: Mikrozensus 1996-2004. 
Table 1

\begin{tabular}{|c|c|c|c|c|c|c|}
\hline \multirow[b]{2}{*}{ Variable } & \multicolumn{3}{|c|}{ Mean } & \multicolumn{3}{|c|}{ Difference West-East } \\
\hline & All & West & East & & Std.Err. & \\
\hline Probability of Substantial Employment & 0.433 & 0.369 & 0.638 & -0.269 & 0.002 & $* *$ \\
\hline Maternal Age & 37.461 & 37.569 & 36.772 & 0.797 & 0.024 & $* *$ \\
\hline Age of Youngest Child & 8.247 & 7.854 & 9.473 & -1.618 & 0.019 & $* *$ \\
\hline \multicolumn{7}{|l|}{ Number of Other Children } \\
\hline$<2$ years & 0.042 & 0.049 & 0.022 & 0.027 & 0.001 & $* *$ \\
\hline 3 to 5 years & 0.094 & 0.109 & 0.048 & 0.061 & 0.001 & $* *$ \\
\hline 6 to 11 years & 0.249 & 0.274 & 0.172 & 0.102 & 0.002 & $* *$ \\
\hline 12 to 18 years & 0.277 & 0.278 & 0.280 & -0.002 & 0.002 & \\
\hline \multicolumn{7}{|l|}{ Numer of Adults in Family } \\
\hline 19 to 26 years & 0.133 & 0.135 & 0.133 & 0.002 & 0.001 & \\
\hline$>=27$ years & 0.005 & 0.006 & 0.004 & 0.002 & 0.000 & $* *$ \\
\hline \multicolumn{7}{|l|}{ Citizenship } \\
\hline German & 0.902 & 0.851 & 0.956 & -0.105 & 0.001 & $* *$ \\
\hline European Union & 0.021 & 0.034 & 0.004 & 0.030 & 0.000 & $* *$ \\
\hline Other & 0.076 & 0.115 & 0.040 & 0.075 & 0.001 & $* *$ \\
\hline \multicolumn{7}{|l|}{ Schooling } \\
\hline No degree / missing information & 0.066 & 0.080 & 0.041 & 0.039 & 0.001 & $* *$ \\
\hline Lower secondary & 0.332 & 0.403 & 0.085 & 0.318 & 0.001 & $* *$ \\
\hline Middle secondary & 0.402 & 0.314 & 0.686 & -0.372 & 0.002 & $* *$ \\
\hline Upper secondary & 0.201 & 0.203 & 0.187 & 0.016 & 0.001 & $* *$ \\
\hline High Skill & 0.185 & 0.150 & 0.303 & -0.153 & 0.001 & $* *$ \\
\hline \multicolumn{7}{|l|}{ Occupation } \\
\hline Agriculture \& Mining & 0.021 & 0.017 & 0.032 & -0.014 & 0.001 & $* *$ \\
\hline Manufacturing & 0.086 & 0.086 & 0.093 & -0.007 & 0.001 & $* *$ \\
\hline Technical Occupation & 0.018 & 0.015 & 0.027 & -0.012 & 0.001 & $* *$ \\
\hline Services & 0.629 & 0.607 & 0.666 & -0.059 & 0.002 & $* *$ \\
\hline Other and Missing Information & 0.246 & 0.275 & 0.182 & 0.092 & 0.001 & $* *$ \\
\hline No Partner & 0.140 & 0.126 & 0.189 & -0.064 & 0.001 & $* *$ \\
\hline \multicolumn{7}{|l|}{ Citizenship of Partner } \\
\hline German & 0.899 & 0.858 & 0.955 & -0.097 & 0.001 & $* *$ \\
\hline European Union & 0.026 & 0.036 & 0.004 & 0.032 & 0.000 & $* *$ \\
\hline Other & 0.076 & 0.106 & 0.040 & 0.066 & 0.001 & $* *$ \\
\hline \multicolumn{7}{|l|}{ Schooling of Partner } \\
\hline No degree / missing information & 0.057 & 0.067 & 0.038 & 0.029 & 0.001 & $* *$ \\
\hline Lower secondary & 0.389 & 0.465 & 0.108 & 0.357 & 0.001 & $* *$ \\
\hline Middle secondary & 0.305 & 0.212 & 0.647 & -0.435 & 0.002 & $* *$ \\
\hline Upper secondary & 0.248 & 0.256 & 0.207 & 0.049 & 0.002 & $* *$ \\
\hline Partner High Skill & 0.261 & 0.261 & 0.240 & 0.022 & 0.001 & $* *$ \\
\hline \multicolumn{7}{|l|}{ Occupation of Partner } \\
\hline Agriculture \& Mining & 0.035 & 0.035 & 0.033 & 0.002 & 0.001 & $* *$ \\
\hline Manufacturing & 0.355 & 0.349 & 0.392 & -0.044 & 0.002 & $* *$ \\
\hline Technical Occupation & 0.104 & 0.108 & 0.076 & 0.032 & 0.001 & $* *$ \\
\hline Senvices & 0.438 & 0.442 & 0.402 & 0.040 & 0.002 & $* *$ \\
\hline Other and Missing Information & 0.069 & 0.066 & 0.097 & -0.031 & 0.001 & $* *$ \\
\hline \multicolumn{7}{|l|}{ Community Size } \\
\hline$<20,000$ inhabitants & 0.459 & 0.442 & 0.481 & -0.039 & 0.002 & $* *$ \\
\hline $20,000-500,000$ inhabitants & 0.413 & 0.442 & 0.337 & 0.105 & 0.002 & $* *$ \\
\hline$>500,000$ inhabitants & 0.128 & 0.116 & 0.183 & -0.067 & 0.001 & $* *$ \\
\hline Unemployment Rate (by state, in \%) & 10.533 & 8.215 & 18.909 & -10.694 & 0.008 & $* *$ \\
\hline Children in Daycare, age 0-2 (by state, in \%) & 10.812 & 4.638 & 32.835 & -28.197 & 0.024 & $* *$ \\
\hline Public Sector Employees (by state, in \%) & 19.690 & 19.025 & 22.193 & -3.167 & 0.008 & $* *$ \\
\hline Number of Observations & 514273 & 401977 & 112296 & & & \\
\hline
\end{tabular}

Note: ${ }^{*},{ }^{*}$ and ${ }^{\circ}$ indicate significant differences at the $0.1,1$, and 5 percent level. The variable number of adults in the family describes the adults excluding a potential partner. Source: Mikrozensus 1996-2004. 
Table 2

Logit Estimation: Probability of Substantial Maternal Employment

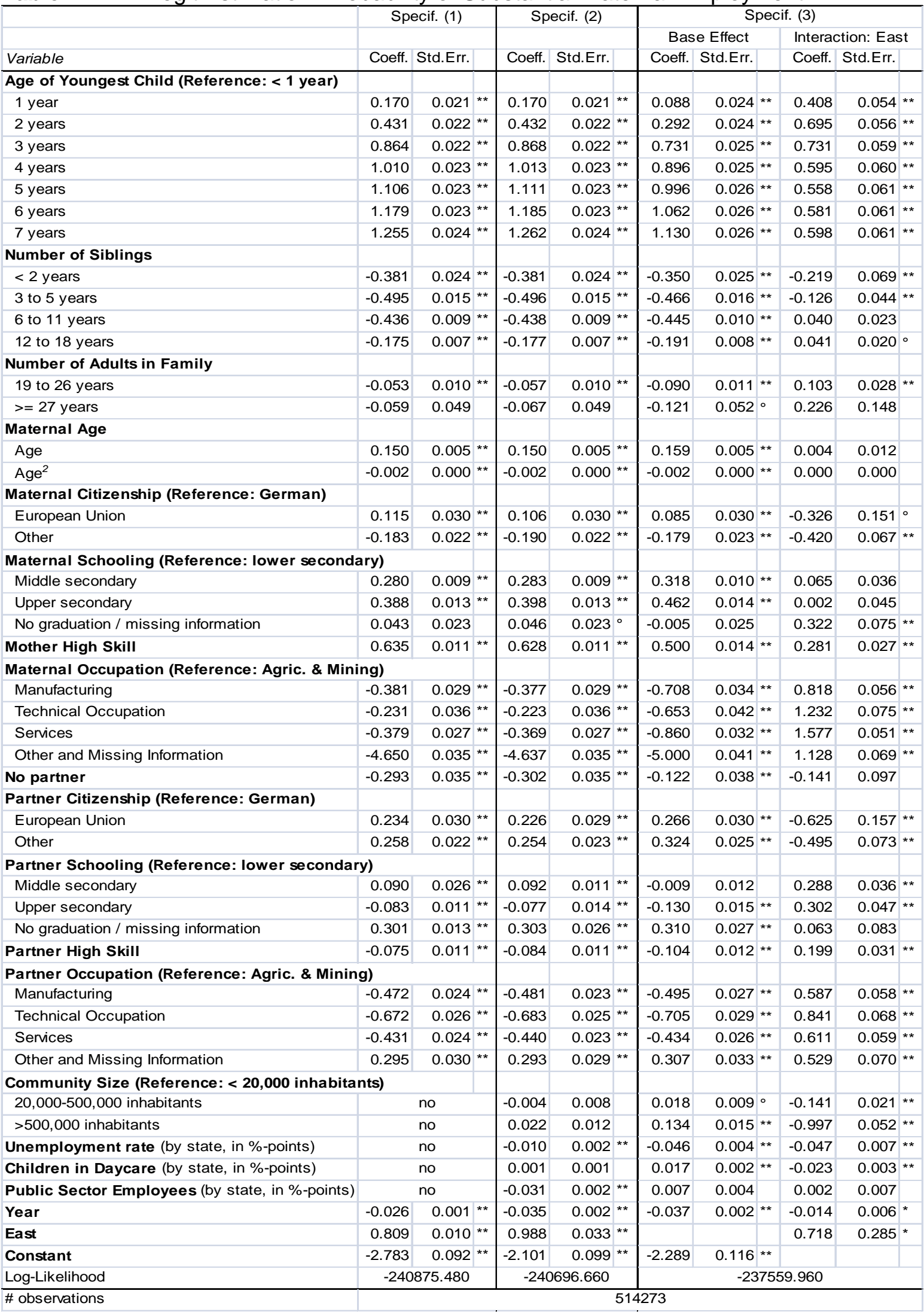

Note: All regressions use 514,273 observations. Additional indicators for children aged 7-18 were considered but not presented to save space. ${ }^{* *},{ }^{*}$ and ${ }^{\circ}$ indicate statistical significance at the $0.1,1$, and 5 percent level. The standard errors are heteroscedasticity robust.

Source: Mikrozensus 1996-2004. 
Table 3 Logit Estimation: Probability of Substantial Maternal Employment

\begin{tabular}{|c|c|c|c|c|c|c|c|c|c|c|c|c|}
\hline \multirow[b]{2}{*}{ Variable } & \multicolumn{3}{|c|}{ Base Effect } & \multicolumn{3}{|c|}{ Interaction: East } & \multicolumn{3}{|c|}{ Interaction: Time } & \multicolumn{3}{|c|}{ Int.: East-Time } \\
\hline & Coeff. & S.E. & & Coeff. & S.E. & & Coeff. & S.E. & & Coeff. & S.E. & \\
\hline \multicolumn{13}{|l|}{ Age of Youngest Child (Reference: $<1$ year) } \\
\hline 1 year & 0.032 & 0.043 & & 0.161 & 0.104 & & 0.014 & 0.009 & & 0.057 & 0.022 & ** \\
\hline 2 years & 0.239 & 0.045 & ** & 0.637 & 0.107 & ** & 0.013 & 0.010 & & 0.012 & 0.022 & \\
\hline 3 years & 0.676 & 0.045 & ** & 0.733 & 0.110 & ** & 0.014 & 0.010 & & -0.001 & 0.023 & \\
\hline 4 years & 0.839 & 0.046 & ** & 0.635 & 0.112 & ** & 0.015 & 0.010 & & -0.008 & 0.023 & \\
\hline 5 years & 0.856 & 0.047 & ** & 0.756 & 0.109 & ** & 0.035 & 0.010 & ** & -0.047 & 0.023 & 0 \\
\hline 6 years & 0.985 & 0.048 & ** & 0.805 & 0.108 & ** & 0.019 & 0.010 & & -0.057 & 0.023 & * \\
\hline 7 years & 1.075 & 0.048 & ** & 0.865 & 0.109 & ** & 0.014 & 0.010 & & -0.072 & 0.024 & ** \\
\hline \multicolumn{13}{|l|}{ Number of Siblings } \\
\hline$<2$ years & -0.351 & 0.047 & ** & -0.288 & 0.139 & $\circ$ & 0.000 & 0.010 & & 0.013 & 0.028 & \\
\hline 3 to 5 years & -0.430 & 0.030 & ** & -0.256 & 0.081 & ** & -0.009 & 0.006 & & 0.034 & 0.017 & 0 \\
\hline 6 to 11 years & -0.428 & 0.018 & ** & 0.134 & 0.041 & ** & -0.004 & 0.004 & & 0.025 & 0.009 & ** \\
\hline 12 to 18 years & -0.148 & 0.015 & $\star \star$ & 0.021 & 0.037 & & -0.011 & 0.003 & ** & 0.005 & 0.008 & \\
\hline \multicolumn{13}{|l|}{ Number of Adults in Family } \\
\hline 19 to 26 years & -0.086 & 0.021 & ** & 0.042 & 0.052 & & -0.001 & 0.004 & & 0.016 & 0.011 & \\
\hline$>=27$ years & -0.219 & 0.096 & $\circ$ & -0.194 & 0.268 & & 0.028 & 0.021 & & 0.100 & 0.059 & \\
\hline \multicolumn{13}{|l|}{ Maternal Age } \\
\hline Age & 0.187 & 0.010 & ** & -0.035 & 0.022 & & -0.007 & 0.002 & ** & 0.008 & 0.005 & \\
\hline $\mathrm{Age}^{2}$ & -0.003 & 0.000 & ** & 0.000 & 0.000 & & 0.000 & 0.000 & ** & 0.000 & 0.000 & \\
\hline \multicolumn{13}{|l|}{ Maternal Citizenship (Reference: German) } \\
\hline European Union & 0.154 & 0.057 & ** & -0.409 & 0.314 & & -0.017 & 0.012 & & 0.020 & 0.062 & \\
\hline Other & -0.029 & 0.047 & & -0.522 & 0.147 & ** & -0.035 & 0.009 & ** & 0.027 & 0.029 & \\
\hline \multicolumn{13}{|c|}{ Maternal Schooling (Reference: lower secondary) } \\
\hline Middle secondary & 0.258 & 0.019 & ** & 0.121 & 0.065 & & 0.015 & 0.004 & ** & -0.009 & 0.014 & \\
\hline Upper secondary & 0.382 & 0.028 & ** & 0.006 & 0.083 & & 0.019 & 0.006 & ** & 0.001 & 0.018 & \\
\hline No graduation / missing information & -0.008 & 0.048 & & 0.285 & 0.139 & $\circ$ & 0.001 & 0.010 & & 0.012 & 0.029 & \\
\hline Mother High Skill & 0.477 & 0.026 & ** & 0.257 & 0.050 & ** & 0.006 & 0.005 & & 0.008 & 0.011 & \\
\hline \multicolumn{13}{|c|}{ Maternal Occupation (Reference: Agric. \& Mining) } \\
\hline Manufacturing & -0.963 & 0.062 & ** & 0.848 & 0.102 & ** & 0.065 & 0.013 & ** & -0.002 & 0.022 & \\
\hline Technical Occupation & -0.825 & 0.078 & ** & 1.266 & 0.137 & ** & 0.044 & 0.016 & ** & -0.004 & 0.030 & \\
\hline Services & -1.044 & 0.059 & ** & 1.555 & 0.095 & ** & 0.048 & 0.012 & ** & 0.009 & 0.021 & \\
\hline Other and Missing Information & -5.329 & 0.075 & ** & 1.455 & 0.122 & ** & 0.084 & 0.016 & ** & -0.094 & 0.028 & ** \\
\hline No partner & -0.194 & 0.072 & ** & -0.074 & 0.178 & & 0.016 & 0.015 & & -0.014 & 0.037 & \\
\hline \multicolumn{13}{|l|}{ Partner Citizenship (Reference: German) } \\
\hline European Union & 0.306 & 0.056 & ** & -0.638 & 0.304 & $\circ$ & -0.010 & 0.012 & & 0.008 & 0.060 & \\
\hline Other & 0.323 & 0.049 & $\star \star$ & -0.409 & 0.141 & ** & -0.002 & 0.010 & & -0.018 & 0.029 & \\
\hline \multicolumn{13}{|l|}{ Partner Schooling (Reference: lower secondary) } \\
\hline Middle secondary & -0.081 & 0.022 & ** & 0.158 & 0.064 & * & 0.018 & 0.005 & ** & 0.040 & 0.014 & \\
\hline Upper secondary & -0.179 & 0.027 & ** & 0.191 & 0.084 & $1^{\circ}$ & 0.012 & 0.006 & $\circ$ & 0.035 & 0.018 & \\
\hline No graduation / missing information & 0.320 & 0.053 & ** & -0.025 & 0.153 & & -0.001 & 0.011 & & 0.028 & 0.031 & \\
\hline Partner High Skill & -0.073 & 0.022 & ** & 0.244 & 0.055 & ** & -0.007 & 0.005 & & -0.013 & 0.012 & \\
\hline Partner Occupation (Reference: Agric. \& Mining & & & & & & & & & & & & \\
\hline Manufacturing & -0.451 & 0.049 & ** & 0.587 & 0.105 & ** & -0.011 & 0.010 & & 0.000 & 0.023 & \\
\hline Technical Occupation & -0.707 & 0.054 & ** & 0.751 & 0.122 & ** & 0.001 & 0.011 & & 0.026 & 0.026 & \\
\hline Services & -0.393 & 0.049 & ** & 0.565 & 0.106 & ** & -0.010 & 0.010 & & 0.011 & 0.023 & \\
\hline Other and Missing Information & 0.358 & 0.062 & ** & 0.582 & 0.127 & ** & -0.012 & 0.013 & & -0.013 & 0.027 & \\
\hline Community Size (Reference: $<20,000$ inhabitan & nts) & & & & & & & & & & & \\
\hline $20,000-500,000$ inhabitants & 0.009 & 0.016 & & -0.103 & 0.038 & ** & 0.003 & 0.003 & & -0.009 & 0.008 & \\
\hline$>500,000$ inhabitants & 0.061 & 0.028 & 0 & -1.184 & 0.100 & ** & 0.019 & 0.006 & $\star \star$ & 0.019 & 0.019 & \\
\hline Unemployment rate (by state, in \%-points) & -0.032 & 0.007 & $\star \star$ & -0.067 & 0.014 & ** & -0.004 & 0.002 & * & 0.001 & 0.004 & \\
\hline Children in Daycare (by state, in \%-points) & 0.020 & 0.005 & $\star *$ & -0.024 & 0.005 & ** & -0.001 & 0.001 & & 0.000 & 0.001 & \\
\hline Public Sector Employees (by state, in \%-points) & 0.005 & 0.007 & & 0.013 & 0.011 & & 0.001 & 0.002 & & -0.001 & 0.002 & \\
\hline East & & & & 0.880 & 0.507 & & & & & & & \\
\hline Year & 0.031 & 0.046 & & -0.041 & 0.110 & & & & & & & \\
\hline Constant & -2.585 & 0.217 & ** & & & & & & & & & \\
\hline Log-Likelihood & & & & & & & 31.71 & & & & & \\
\hline
\end{tabular}

Note: All regressions use 514,273 observations. Additional indicators for children aged 7-18 were considered but not presented to save space. ${ }^{* *},{ }^{*}$ and ${ }^{\circ}$ indicate statistical significance at the $0.1,1$, and 5 percent level. The standard errors (S.E.) are heteroscedasticity robust. Source: Mikrozensus 1996-2004. 
Table 4.1 Logit Estimation: Probability of Substantial Maternal Employment - High Skill Mothers

\begin{tabular}{|c|c|c|c|c|c|c|c|c|c|c|c|}
\hline \multirow[b]{2}{*}{ Variable } & \multicolumn{3}{|c|}{ Base Effect } & \multicolumn{3}{|c|}{ Interaction: East } & \multicolumn{2}{|c|}{ Interaction: Time } & \multicolumn{3}{|c|}{ Int.: East·Time } \\
\hline & Coeff. & Std.Err. & & Coeff. & Std.Err. & & Coeff. & Std.Err. & Coeff. & Std.Err. & \\
\hline \multicolumn{12}{|c|}{ Age of Youngest Child (Reference: $<1$ year) } \\
\hline 1 year & 0.292 & 0.094 & ** & 0.117 & 0.188 & & 0.002 & 0.019 & 0.066 & 0.038 & \\
\hline 2 years & 0.419 & 0.100 & )** & 0.980 & 0.202 & ** & 0.009 & 0.020 & -0.038 & 0.041 & \\
\hline 3 years & 0.914 & 0.103 & ** & 0.846 & 0.216 & ** & -0.003 & 0.021 & 0.025 & 0.045 & \\
\hline 4 years & 0.923 & 0.108 & ** & 0.871 & 0.228 & $\star \star$ & 0.016 & 0.022 & 0.023 & 0.048 & \\
\hline 5 years & 1.079 & 0.111 & ** & 1.180 & 0.227 & $\star \star$ & 0.012 & 0.023 & -0.063 & 0.047 & \\
\hline 6 years & 1.203 & 0.114 & ** & 1.251 & 0.227 & $\star \star$ & -0.007 & 0.023 & -0.056 & 0.047 & \\
\hline 7 years & 1.173 & 0.116 & ** & 1.486 & 0.225 & $\star *$ & 0.007 & 0.024 & -0.100 & $0.048^{\circ}$ & \\
\hline 8 years & 1.394 & 0.117 & ** & 1.209 & 0.225 & ** & -0.023 & 0.024 & -0.061 & 0.050 & \\
\hline 9 years & 1.393 & 0.117 & ** & 1.174 & 0.230 & ** & 0.007 & 0.024 & -0.038 & 0.052 & \\
\hline 10 years & 1.323 & 0.120 & ** & 1.675 & 0.248 & ** & 0.034 & 0.025 & -0.132 & 0.055 * & \\
\hline 11 years & 1.539 & 0.122 & ** & 1.364 & 0.249 & ** & -0.004 & 0.025 & -0.048 & 0.054 & \\
\hline 12 years & 1.640 & 0.126 & ** & 1.393 & 0.261 & ** & 0.020 & 0.026 & -0.089 & 0.054 & \\
\hline 13 years & 1.738 & 0.128 & $3 *$ & 1.308 & 0.253 & ** & -0.011 & 0.026 & -0.063 & 0.052 & \\
\hline 14 years & 1.783 & 0.131 & ** & 0.931 & 0.251 & ** & 0.010 & 0.027 & -0.011 & 0.052 & \\
\hline 15 years & 1.832 & 0.134 & ** & 1.117 & 0.260 & ** & 0.010 & 0.027 & -0.025 & 0.053 & \\
\hline 16 years & 1.686 & 0.135 & ** & 1.391 & 0.266 & ** & 0.036 & 0.028 & -0.086 & 0.054 & \\
\hline 17 years & 1.743 & 0.142 & ** & 1.420 & 0.276 & ** & 0.052 & 0.029 & -0.100 & 0.057 & \\
\hline 18 years & 1.804 & 0.146 & ** & 1.291 & 0.279 & ** & 0.035 & 0.030 & -0.059 & 0.058 & \\
\hline \multicolumn{12}{|l|}{ Number of Siblings } \\
\hline$<2$ years & -0.279 & 0.098 & 3 ** & -0.327 & 0.241 & & -0.014 & 0.020 & 0.044 & 0.046 & \\
\hline 3 to 5 years & -0.469 & 0.066 & ** & -0.276 & 0.148 & & -0.006 & 0.013 & 0.076 & 0.030 * & * \\
\hline 6 to 11 years & -0.415 & 0.042 & ** & 0.154 & 0.092 & & 0.002 & 0.009 & -0.015 & 0.020 & \\
\hline 12 to 18 years & -0.215 & 0.040 & ** & 0.143 & 0.088 & & -0.007 & 0.008 & -0.007 & 0.018 & \\
\hline \multicolumn{12}{|l|}{ Number of Adults in Family } \\
\hline 19 to 26 years & -0.191 & 0.057 & ** & 0.126 & 0.124 & & 0.005 & 0.011 & 0.024 & 0.026 & \\
\hline$>=27$ years & -0.559 & 0.316 & & -0.377 & 0.648 & & 0.162 & $0.072^{\circ}$ & -0.047 & 0.139 & \\
\hline \multicolumn{12}{|l|}{ Maternal Age } \\
\hline Age & 0.194 & 0.031 & ** & 0.002 & 0.057 & & -0.009 & 0.006 & 0.004 & 0.012 & \\
\hline $\operatorname{Age}^{2}$ & -0.003 & 0.000 & ** & -0.001 & 0.001 & & 0.000 & 0.000 & 0.000 & 0.000 & \\
\hline \multicolumn{12}{|c|}{ Maternal Citizenship (Reference: German) } \\
\hline European Union & -0.215 & 0.134 & & -1.030 & 0.573 & & 0.012 & 0.027 & 0.111 & 0.110 & \\
\hline Other & -0.641 & 0.114 & ** & -0.832 & 0.288 & ** & 0.012 & 0.022 & -0.077 & 0.057 & \\
\hline \multicolumn{12}{|c|}{ Maternal Schooling (Reference: lower secondary) } \\
\hline Middle secondary & -0.150 & 0.098 & & 0.513 & 0.313 & & 0.030 & 0.021 & -0.046 & 0.072 & \\
\hline Upper secondary & 0.040 & 0.095 & & 0.329 & 0.313 & & 0.039 & 0.020 & -0.029 & 0.072 & \\
\hline No graduation / missing information & -0.068 & 0.321 & & 1.456 & 0.754 & & -0.017 & 0.058 & -0.133 & 0.135 & \\
\hline \multicolumn{12}{|c|}{ Maternal Occupation (Reference: Agric. \& Mining) } \\
\hline Manufacturing & -1.350 & 0.216 & ** & 1.810 & 0.370 & ** & 0.149 & 0.043 ** & -0.211 & 0.082 * & 2 * \\
\hline Technical Occupation & -1.084 & 0.207 & ** & 2.054 & 0.351 & ** & 0.125 & $0.041 *$ & -0.192 & 0.079 * & 9 * \\
\hline Services & -1.365 & 0.189 & ** & 2.416 & 0.314 & ** & 0.152 & 0.037 ** & -0.184 & 0.071 * & ** \\
\hline Other and Missing Information & -5.755 & 0.233 & ** & 2.041 & 0.365 & ** & 0.153 & $0.047 *$ & -0.213 & 0.082 * & 2 ** \\
\hline \multicolumn{12}{|l|}{ (covariates omitted) } \\
\hline East & 0.840 & 1.312 & & & & & & & & & \\
\hline Year & -0.006 & 0.138 & & -0.103 & 0.284 & & & & & & \\
\hline Constant & -2.896 & 0.673 & ** & & & & & & & & \\
\hline Log-Likelihood (number of obs.) & \multicolumn{6}{|c|}{-42740.973} & \multicolumn{5}{|c|}{$(95,165)$} \\
\hline Tests of Joint Significance: & $\mathrm{X}^{2}(\mathrm{dF})$ & $\mathrm{p}$-value & & $\mathrm{X}^{2}(\mathrm{dF})$ & $\mathrm{p}$-value & & $\mathrm{X}^{2}(\mathrm{dF})$ & $p$-value & $\mathrm{x}^{2}(\mathrm{dF})$ & $p$-value & \\
\hline Age of Youngest Child & $381.33(18)$ & 0.00 & $* * 9$ & 7.61(18) & 0.00 & $* \star L$ & $5.75(18)$ & 0.61 & $9.85(18)$ & $0.04^{\circ}$ & \\
\hline
\end{tabular}


Table 4.2 Logit Estimation: Probability of Substantial Maternal Employment - Low and Medium Skilled Mothers

\begin{tabular}{|c|c|c|c|c|c|c|c|c|c|c|c|c|}
\hline \multirow[b]{2}{*}{ Variable } & \multicolumn{3}{|c|}{ Base Effect } & \multicolumn{3}{|c|}{ Interaction: East } & \multicolumn{3}{|c|}{ Interaction: Time } & \multicolumn{3}{|c|}{ Int.: East.Time } \\
\hline & Coeff. & Std.Err. & & Coeff. & Std.Err. & & Coeff. & Std.Err. & & Coeff. & Std.Err. & \\
\hline \multicolumn{13}{|c|}{ Age of Youngest Child (Reference: $<1$ year) } \\
\hline 1 year & -0.037 & 0.049 & & 0.146 & 0.121 & & 0.014 & 0.011 & & 0.051 & 0.025 & $5^{\circ}$ \\
\hline 2 years & 0.192 & 0.050 & ** & 0.477 & 0.124 & ** & 0.011 & 0.011 & & 0.027 & 0.026 & \\
\hline 3 years & 0.613 & 0.050 & ** & 0.625 & 0.125 & ** & 0.016 & 0.011 & & -0.009 & 0.026 & \\
\hline 4 years & 0.808 & 0.051 & ** & 0.499 & 0.127 & ** & 0.012 & 0.011 & & -0.019 & 0.027 & \\
\hline 5 years & 0.796 & 0.052 & ** & 0.581 & 0.124 & ** & 0.038 & 0.011 & ** & -0.052 & 0.027 & \\
\hline 6 years & 0.925 & 0.053 & ** & 0.618 & 0.123 & ** & 0.023 & 0.011 & $\circ$ & -0.064 & 0.027 & * * \\
\hline 7 years & 1.040 & 0.053 & ** & 0.634 & 0.124 & $\star \star$ & 0.014 & 0.012 & & -0.070 & 0.028 & $3 *$ \\
\hline 8 years & 1.223 & 0.054 & ** & 0.546 & 0.125 & ** & -0.005 & 0.012 & & -0.079 & 0.028 & 3 ** \\
\hline 9 years & 1.362 & 0.054 & ** & 0.518 & 0.127 & $\star \star$ & -0.016 & 0.012 & & -0.069 & 0.028 & * \\
\hline 10 years & 1.381 & 0.055 & ** & 0.594 & 0.130 & ** & 0.001 & 0.012 & & -0.087 & 0.029 & ** \\
\hline 11 years & 1.477 & 0.056 & ** & 0.493 & 0.133 & $\star \star$ & -0.002 & 0.012 & & -0.071 & 0.029 & * \\
\hline 12 years & 1.724 & 0.057 & $\star \star$ & 0.197 & 0.137 & & -0.025 & 0.012 & $\circ$ & -0.029 & 0.030 & \\
\hline 13 years & 1.754 & 0.058 & ** & 0.387 & 0.137 & ** & -0.011 & 0.012 & & -0.059 & 0.029 & 0 \\
\hline 14 years & 1.804 & 0.058 & ** & 0.288 & 0.140 & 0 & 0.002 & 0.012 & & -0.058 & 0.029 & 0 \\
\hline 15 years & 1.886 & 0.058 & ** & 0.170 & 0.140 & & 0.003 & 0.013 & & -0.064 & 0.029 & ${ }^{\circ}$ \\
\hline 16 years & 1.945 & 0.060 & ** & 0.239 & 0.143 & & 0.009 & 0.013 & & -0.066 & 0.030 & $0^{\circ}$ \\
\hline 17 years & 2.045 & 0.061 & ** & 0.035 & 0.145 & & -0.003 & 0.013 & & -0.029 & 0.030 & \\
\hline 18 years & 2.091 & 0.062 & ** & 0.171 & 0.148 & & 0.004 & 0.013 & & -0.050 & 0.031 & \\
\hline \multicolumn{13}{|l|}{ Number of Siblings } \\
\hline$<2$ years & -0.378 & 0.053 & ** & -0.214 & 0.163 & & 0.006 & 0.012 & & -0.004 & 0.033 & \\
\hline 3 to 5 years & -0.428 & 0.034 & ** & -0.214 & 0.095 & 0 & -0.010 & 0.007 & & 0.013 & 0.020 & \\
\hline 6 to 11 years & -0.440 & 0.020 & ** & 0.132 & 0.046 & $\star \star$ & -0.005 & 0.004 & & -0.032 & 0.010 & ** \\
\hline 12 to 18 years & -0.141 & 0.017 & ** & -0.012 & 0.041 & & -0.011 & 0.004 & ** & 0.006 & 0.009 & \\
\hline \multicolumn{13}{|l|}{ Number of Adults in Family } \\
\hline 19 to 26 years & -0.074 & 0.022 & ** & 0.019 & 0.058 & & -0.002 & 0.005 & & 0.011 & 0.012 & \\
\hline$>=27$ years & -0.168 & 0.101 & & -0.174 & 0.294 & & 0.014 & 0.022 & & 0.132 & 0.066 & 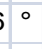 \\
\hline \multicolumn{13}{|l|}{ Maternal Age } \\
\hline Age & 0.191 & 0.011 & ** & -0.036 & 0.025 & & -0.006 & 0.002 & ** & 0.011 & 0.005 & $5 \circ$ \\
\hline $\mathrm{Age}^{2}$ & -0.003 & 0.000 & ** & 0.000 & 0.000 & & 0.000 & 0.000 & ** & 0.000 & 0.000 & ** \\
\hline \multicolumn{13}{|l|}{ German) } \\
\hline European Union & 0.230 & 0.064 & ** & 0.012 & 0.335 & & -0.023 & 0.013 & & -0.025 & 0.070 & \\
\hline Other & 0.087 & 0.052 & & -0.393 & 0.161 & * & -0.044 & 0.010 & ** & 0.061 & 0.032 & \\
\hline \multicolumn{13}{|c|}{ Maternal Schooling (Reference: lower secondary) } \\
\hline Middle secondary & 0.285 & 0.019 & ** & 0.119 & 0.066 & & 0.014 & 0.004 & ** & -0.006 & 0.014 & \\
\hline Upper secondary & 0.385 & 0.032 & ** & 0.105 & 0.108 & & 0.017 & 0.006 & ** & -0.006 & 0.022 & \\
\hline No graduation / missing information & -0.030 & 0.049 & & 0.252 & 0.138 & & 0.003 & 0.010 & & 0.012 & 0.029 & \\
\hline \multicolumn{13}{|c|}{ Maternal Occupation (Reference: Agric. \& Mining) } \\
\hline Manufacturing & -0.934 & 0.106 & ** & 0.760 & 0.014 & ** & 0.054 & 0.014 & ** & 0.019 & 0.023 & \\
\hline Technical Occupation & -0.818 & 0.164 & ** & 1.163 & 0.019 & ** & 0.044 & 0.019 & * & 0.020 & 0.036 & \\
\hline Services & -1.014 & 0.099 & ** & 1.440 & 0.013 & ** & 0.035 & 0.013 & ** & 0.027 & 0.022 & \\
\hline Other and Missing Information & -5.284 & 0.131 & ** & 1.452 & 0.017 & $\star \star$ & 0.078 & 0.017 & ** & -0.098 & 0.030 & ** \\
\hline \multicolumn{13}{|l|}{ (covariates omitted) } \\
\hline East & 0.765 & 0.556 & & & & & & & & & & \\
\hline Year & 0.038 & 0.049 & & -0.098 & 0.121 & & & & & & & \\
\hline Constant & -2.477 & 0.233 & $3 * *$ & & & & & & & & & \\
\hline Log-Likelihood (number of obs.) & \multicolumn{6}{|c|}{193896.17} & \multicolumn{6}{|c|}{$(419,108)$} \\
\hline Tests of Joint Significance: & $\mathrm{X}^{2}(\mathrm{dF})$ & $p$-value & & $\mathrm{X}^{2}(\mathrm{dF})$ & $\mathrm{p}$-value & & $\mathrm{X}^{2}(\mathrm{dF})$ & $\mathrm{p}$-value & & $\mathrm{X}^{2}(\mathrm{dF})$ & p-value & \\
\hline Age of Youngest Child & $2556.77(18)$ & 0.000 & **) & $3.16(18)$ & 0.000 & ** & $58.01(18)$ & 0.000 & ** & $52.73(18)$ & 0.000 & \\
\hline
\end{tabular}

Note: Partner and regional characteristics are omitted to save space. Details are available upon request from the authors. ${ }^{* *},{ }^{*}$ and ${ }^{\circ}$ indicate statistical significance at the $0.1,1$, and 5 percent level. The standard errors are heteroscedasticity robust.

Source: Mikrozensus 1996-2004. 
Table A.1 Descriptive Statistics by Region and Year: Mean Values

\begin{tabular}{|c|c|c|c|c|c|}
\hline & West 96 & East 96 & West 04 & East 04 & \\
\hline Variable & $(1)$ & $(2)$ & (3) & $(4)$ & \\
\hline Probability of Substantial Employment & 0.364 & 0.672 & 0.365 & 0.598 & $* *$ \\
\hline Maternal Age & 36.849 & 35.889 & 38.391 & 37.382 & \\
\hline Age of Youngest Child & 7.696 & 9.261 & 8.121 & 9.391 & $* *$ \\
\hline \multicolumn{6}{|l|}{ Number of Siblings } \\
\hline$<2$ years & 0.050 & 0.016 & 0.043 & 0.027 & $* *$ \\
\hline 3 to 5 years & 0.115 & 0.050 & 0.102 & 0.059 & $* *$ \\
\hline 6 to 11 years & 0.271 & 0.212 & 0.268 & 0.137 & $* *$ \\
\hline 12 to 18 years & 0.271 & 0.290 & 0.290 & 0.241 & $* *$ \\
\hline \multicolumn{6}{|l|}{ Numer of Adults in Family } \\
\hline 19 to 26 years & 0.132 & 0.112 & 0.144 & 0.142 & $* *$ \\
\hline$>=27$ years & 0.006 & 0.003 & 0.005 & 0.004 & \\
\hline \multicolumn{6}{|l|}{ Maternal Citizenship } \\
\hline German & 0.849 & 0.964 & 0.848 & 0.944 & $* *$ \\
\hline European Union & 0.035 & 0.004 & 0.033 & 0.004 & \\
\hline Other & 0.116 & 0.032 & 0.119 & 0.052 & $* *$ \\
\hline \multicolumn{6}{|l|}{ Maternal Schooling } \\
\hline no graduation / missing information & 0.086 & 0.044 & 0.093 & 0.058 & \\
\hline lower secondary & 0.458 & 0.083 & 0.349 & 0.082 & $* *$ \\
\hline middle secondary & 0.284 & 0.704 & 0.326 & 0.647 & $* *$ \\
\hline upper secondary & 0.172 & 0.168 & 0.232 & 0.214 & $*$ \\
\hline Mother High Skill & 0.132 & 0.301 & 0.168 & 0.293 & $* *$ \\
\hline \multicolumn{6}{|l|}{ Maternal Occupation } \\
\hline Agriculture \& Mining & 0.019 & 0.034 & 0.016 & 0.024 & $* *$ \\
\hline Manufacturing & 0.093 & 0.095 & 0.076 & 0.087 & \\
\hline Technical Occupation & 0.015 & 0.031 & 0.016 & 0.020 & $* *$ \\
\hline Services & 0.560 & 0.661 & 0.631 & 0.672 & $* *$ \\
\hline Other and Missing Information & 0.314 & 0.178 & 0.261 & 0.197 & $* *$ \\
\hline No Partner & 0.110 & 0.161 & 0.143 & 0.225 & $* *$ \\
\hline \multicolumn{6}{|l|}{ Partner Citizenship } \\
\hline German & 0.851 & 0.960 & 0.863 & 0.946 & $* *$ \\
\hline European Union & 0.036 & 0.004 & 0.036 & 0.005 & \\
\hline Other & 0.113 & 0.036 & 0.101 & 0.049 & $* *$ \\
\hline \multicolumn{6}{|l|}{ Partner Schooling } \\
\hline no graduation / missing information & 0.069 & 0.040 & 0.079 & 0.057 & $\circ$ \\
\hline lower secondary & 0.507 & 0.112 & 0.420 & 0.094 & $* *$ \\
\hline middle secondary & 0.192 & 0.660 & 0.221 & 0.621 & $* *$ \\
\hline upper secondary & 0.232 & 0.189 & 0.281 & 0.228 & \\
\hline Partner High Skill & 0.258 & 0.247 & 0.259 & 0.222 & $* *$ \\
\hline \multicolumn{6}{|l|}{ Partner Occupation } \\
\hline Agriculture \& Mining & 0.037 & 0.035 & 0.035 & 0.031 & \\
\hline Manufacturing & 0.358 & 0.413 & 0.327 & 0.347 & $* *$ \\
\hline Technical Occupation & 0.105 & 0.078 & 0.111 & 0.078 & \\
\hline Services & 0.431 & 0.394 & 0.453 & 0.426 & \\
\hline Other and Missing Information & 0.069 & 0.081 & 0.074 & 0.119 & $* *$ \\
\hline \multicolumn{6}{|l|}{ Community Size } \\
\hline$<20,000$ inhabitants & 0.443 & 0.461 & 0.437 & 0.472 & $\circ$ \\
\hline $20,000-500,000$ inhabitants & 0.440 & 0.359 & 0.448 & 0.335 & $* *$ \\
\hline$>500,000$ inhabitants & 0.118 & 0.180 & 0.115 & 0.193 & $* *$ \\
\hline Unemployment Rate (by state, in \%) & 8.933 & 18.513 & 7.821 & 18.403 & $* *$ \\
\hline Children in Daycare, $0-2$ years (by state, in \%) & 3.856 & 30.985 & 5.940 & 35.948 & $* *$ \\
\hline Public Sector Employees (by state, in \%) & 19.778 & 24.288 & 18.851 & 20.332 & $* *$ \\
\hline Number of Observations & 44668 & 14327 & 44081 & 10962 & \\
\hline
\end{tabular}

Note: ${ }^{*},{ }^{*}$, and ${ }^{\circ}$ indicate statistical significance of East-West differences over time at the 0.1 , 1 , and 5 percent level.

Source: Mikrozensus $(1996,2004)$ 
Table A.2 Descriptive Statistics by Region and Year: Mean Values

\begin{tabular}{|c|c|c|c|c|c|c|c|c|}
\hline \multirow[b]{3}{*}{ Variable } & \multicolumn{4}{|c|}{ Low Skill } & \multicolumn{4}{|c|}{ High Skill } \\
\hline & \multirow{2}{*}{$\begin{array}{r}\text { West } 96 \\
(1)\end{array}$} & \multicolumn{2}{|c|}{ East 96 West 04} & \multirow{2}{*}{$\begin{array}{r}\text { East } 04 \\
(4)\end{array}$} & \multirow{2}{*}{$\begin{array}{r}\text { West } 96 \\
(1)\end{array}$} & \multicolumn{2}{|c|}{ East 96 West 04} & \multirow{2}{*}{$\begin{array}{r}\text { East } 04 \\
(4)\end{array}$} \\
\hline & & (2) & (3) & & & (2) & (3) & \\
\hline Probability of Substantial Employment & 0.346 & 0.608 & 0.339 & 0.522 & 0.481 & 0.820 & 0.497 & 0.782 \\
\hline Maternal Age & 36.541 & 35.372 & 38.014 & 36.686 & 38.876 & 37.087 & 40.266 & 39.058 \\
\hline Age of Youngest Child & 7.727 & 9.093 & 8.196 & 9.208 & 7.491 & 9.651 & 7.748 & 9.833 \\
\hline \multicolumn{9}{|l|}{ Number of Siblings } \\
\hline$<2$ years & 0.049 & 0.018 & 0.040 & 0.028 & 0.057 & 0.010 & 0.058 & 0.023 \\
\hline 3 to 5 years & 0.114 & 0.054 & 0.100 & 0.060 & 0.116 & 0.041 & 0.115 & 0.054 \\
\hline 6 to 11 years & 0.269 & 0.219 & 0.271 & 0.141 & 0.283 & 0.196 & 0.253 & 0.127 \\
\hline 12 to 18 years & 0.272 & 0.285 & 0.299 & 0.238 & 0.262 & 0.301 & 0.249 & 0.246 \\
\hline \multicolumn{9}{|l|}{ Numer of Adults in Family } \\
\hline 19 to 26 years & 0.135 & 0.111 & 0.146 & 0.135 & 0.113 & 0.113 & 0.133 & 0.159 \\
\hline$>=27$ years & 0.007 & 0.004 & 0.006 & 0.004 & 0.003 & 0.003 & 0.002 & 0.002 \\
\hline \multicolumn{9}{|l|}{ Maternal Citizenship } \\
\hline German & 0.842 & 0.957 & 0.838 & 0.934 & 0.900 & 0.980 & 0.897 & 0.968 \\
\hline European Union & 0.035 & 0.004 & 0.034 & 0.004 & 0.030 & 0.004 & 0.030 & 0.006 \\
\hline Other & 0.123 & 0.039 & 0.129 & 0.063 & 0.070 & 0.015 & 0.074 & 0.026 \\
\hline \multicolumn{9}{|l|}{ Maternal Schooling } \\
\hline no graduation / missing information & 0.098 & 0.063 & 0.110 & 0.078 & 0.005 & 0.002 & 0.009 & 0.007 \\
\hline lower secondary & 0.520 & 0.115 & 0.412 & 0.113 & 0.050 & 0.008 & 0.036 & 0.006 \\
\hline middle secondary & 0.301 & 0.783 & 0.360 & 0.736 & 0.177 & 0.522 & 0.159 & 0.432 \\
\hline upper secondary & 0.082 & 0.039 & 0.119 & 0.073 & 0.768 & 0.469 & 0.795 & 0.554 \\
\hline \multicolumn{9}{|l|}{ Maternal Occupation } \\
\hline Agriculture \& Mining & 0.020 & 0.044 & 0.016 & 0.030 & 0.014 & 0.011 & 0.013 & 0.008 \\
\hline Manufacturing & 0.103 & 0.127 & 0.086 & 0.112 & 0.021 & 0.022 & 0.025 & 0.026 \\
\hline Technical Occupation & 0.011 & 0.020 & 0.011 & 0.013 & 0.043 & 0.057 & 0.042 & 0.039 \\
\hline Services & 0.535 & 0.590 & 0.605 & 0.603 & 0.723 & 0.826 & 0.762 & 0.840 \\
\hline Other and Missing Information & 0.331 & 0.219 & 0.281 & 0.242 & 0.198 & 0.084 & 0.158 & 0.087 \\
\hline No Partner & 0.110 & 0.169 & 0.145 & 0.243 & 0.111 & 0.144 & 0.135 & 0.182 \\
\hline \multicolumn{9}{|l|}{ Partner Citizenship } \\
\hline German & 0.840 & 0.952 & 0.849 & 0.935 & 0.923 & 0.979 & 0.931 & 0.969 \\
\hline European Union & 0.038 & 0.004 & 0.038 & 0.005 & 0.024 & 0.004 & 0.024 & 0.006 \\
\hline Other & 0.122 & 0.044 & 0.113 & 0.060 & 0.053 & 0.018 & 0.045 & 0.025 \\
\hline \multicolumn{9}{|l|}{ Partner Schooling } \\
\hline no graduation / missing information & 0.079 & 0.055 & 0.092 & 0.077 & 0.007 & 0.005 & 0.012 & 0.011 \\
\hline lower secondary & 0.561 & 0.144 & 0.478 & 0.122 & 0.149 & 0.041 & 0.134 & 0.030 \\
\hline middle secondary & 0.197 & 0.707 & 0.234 & 0.676 & 0.164 & 0.553 & 0.156 & 0.501 \\
\hline upper secondary & 0.164 & 0.094 & 0.196 & 0.125 & 0.679 & 0.401 & 0.698 & 0.458 \\
\hline Partner High Skill & 0.196 & 0.140 & 0.182 & 0.119 & 0.667 & 0.495 & 0.641 & 0.472 \\
\hline \multicolumn{9}{|l|}{ Partner Occupation } \\
\hline Agriculture \& Mining & 0.038 & 0.038 & 0.035 & 0.037 & 0.032 & 0.027 & 0.032 & 0.016 \\
\hline Manufacturing & 0.393 & 0.459 & 0.367 & 0.391 & 0.128 & 0.309 & 0.131 & 0.248 \\
\hline Technical Occupation & 0.095 & 0.051 & 0.097 & 0.054 & 0.168 & 0.137 & 0.179 & 0.133 \\
\hline Services & 0.402 & 0.359 & 0.421 & 0.378 & 0.624 & 0.471 & 0.609 & 0.531 \\
\hline Other and Missing Information & 0.072 & 0.093 & 0.079 & 0.140 & 0.048 & 0.055 & 0.049 & 0.072 \\
\hline \multicolumn{9}{|l|}{ Community Size } \\
\hline$<20,000$ inhabitants & 0.449 & 0.476 & 0.444 & 0.486 & 0.401 & 0.425 & 0.402 & 0.440 \\
\hline $20,000-500,000$ inhabitants & 0.436 & 0.343 & 0.447 & 0.320 & 0.463 & 0.397 & 0.456 & 0.370 \\
\hline$>500,000$ inhabitants & 0.115 & 0.181 & 0.109 & 0.194 & 0.136 & 0.179 & 0.142 & 0.190 \\
\hline Unemployment Rate (by state, in \%) & 8.944 & 18.516 & 7.840 & 18.429 & 8.857 & 18.505 & 7.724 & 18.339 \\
\hline Children in Daycare, $0-2$ years (by state, in \%) & 3.851 & 31.001 & 5.918 & 36.183 & 3.889 & 30.948 & 6.045 & 35.382 \\
\hline Public Sector Employees (by state, in \%) & 19.786 & 24.291 & 18.882 & 20.416 & 19.725 & 24.280 & 18.701 & 20.132 \\
\hline Number of Observations & 38675 & 9991 & 36585 & 7734 & 5993 & 4336 & 7496 & 3228 \\
\hline
\end{tabular}

Source: Mikrozensus (1996, 2004) 